\title{
Carbocyclic-fused $N, N, N$-pincer ligands as ring-strain adjustable supports for iron and cobalt catalysts in ethylene oligo-/polymerization
}

Zheng Wang, ${ }^{\mathrm{a}, \mathrm{b}}$ Gregory A. Solan, ${ }^{\text {a,c }}$ Wenjuan, Zhang, ${ }^{* a, d}$ and Wen-Hua Sun*a,b,e

${ }^{\text {a }}$ Key Laboratory of Engineering Plastics and Beijing National Laboratory for Molecular Science, Institute of Chemistry, Chinese Academy of Sciences, Beijing 100190, China.

${ }^{\mathrm{b}}$ CAS Research/Education Center for Excellence in Molecular Sciences, University of Chinese Academy of Sciences, Beijing 100049, China.

${ }^{c}$ Department of Chemistry, University of Leicester, University Road, Leicester LE1 7RH, UK.

d School of Materials Science and Engineering, Beijing Institute of Fashion Technology, Beijing 100029, China.

${ }^{\text {e }}$ State Key Laboratory for Oxo Synthesis and Selective Oxidation, Lanzhou Institute of Chemical Physics, Chinese Academy of Sciences, Lanzhou 730000, China.

\section{Contents}

1. Introduction

2. $\mathrm{Fe} / \mathrm{Co}$ pre-catalysts bearing bis(arylimino)pyridines

3. Aryl-fused $N, N, N$-ligands and their Fe/Co pre-catalysts

4. Cycloalkyl-fused bis(arylimino)pyridines and their $\mathrm{Fe} / \mathrm{Co}$ pre-catalysts

5. Mechanistic understanding of $\mathrm{Fe} / \mathrm{Co}$ catalysts in ethylene polymerization

5.1 The active iron species

5.2 The active cobalt species

5.3 Propagation, chain transfer pathways and theoretical studies

6. Conclusions and outlook

Acknowledgements

References

\begin{abstract}
Recent progress in the application of homogeneous iron and cobalt catalysts in ethylene oligo-/polymerization is reviewed with particular emphasis placed on the tuning of catalyst performance through the introduction of controlled amounts of ring strain to the ligand frame. While new examples of catalysts bearing the prototypical
\end{abstract}


bis(arylimino)pyridine continue to emerge in the literature, the last decade has witnessed a number of key advances concerned with the fusion of carbocyclic units to the $N, N, N$-pincer manifold with a view to enhancing both the catalytic activities and thermal stability of their resultant catalysts. Some notable examples include iron complexes containing aryl-fused imino-phenanthroline ligands, which have proved highly active catalysts for ethylene oligomerization and indeed have shown considerable industrial promise on the pilot plant scale. Elsewhere, bis(arylimino)pyridines incorporating singly or doubly fused cycloalkyl units with the ring sizes anywhere between five- and eight-membered have been systematically developed and have proved versatile supports for both metal centers. More significantly, clear correlations between structure and activity as well as oligo-/polymer properties are a feature of these strain-adjustable catalysts. In many cases, linear vinyl-polyethylenes are accessible which are in demand for the production of long-chain branched copolymers, functional polymers as well as coating materials.

Keywords: Iron/cobalt catalysts; N,N,N-Pincer ligands; Ethylene oligo-/polymerization; Bis(arylimino)pyridine; Imino-phenanthroline; $\alpha$-Olefins; $\quad$ Fused units; Vinyl-polyethylenes; Functional polymers.

\section{Introduction}

Over recent years there have been some notable advances in the development of well-defined homogeneous catalysts based on earth-abundant base metals [1-12]. In particular, iron and cobalt complexes supported by pincer ligands have been shown to promote a wide variety of important transformations including, (i) the hydrogenation of olefins, carbonyl compounds, carboxylic acid derivatives and $\mathrm{CO}_{2}$ [13-29], (ii) the dehydrogenation of alcohols, amines and alkanes [30-35], (iii) transfer hydrogenation reactions [36] and (iv) dehydrogenative cross-coupling [37-39]. Perhaps more significantly, iron and cobalt complexes have proved potent catalysts for not only olefin polymerization [40-51] but also for shorter chain oligomerization reactions [43,46,51]. 
Indeed, the recent integration of iron catalyst technology into a five-hundred ton process for making $\alpha$-olefins in China highlights the vast industrial significance of such catalysts [46].

In order to explore the full scope and versatility of these industrially promising polymerization catalysts we have, over the last decade or so, been concerned with a systematic exploration of the structural features of the pre-catalyst and in particular the auxiliary ligand that dictates catalyst performance. The first examples of iron and cobalt catalysts displaying high activity were first disclosed some twenty years ago [52-56]. Indeed, these first generation systems based on bis(arylimino)pyridine pincer ligands (A, Figure 1) were capable of generating either oligomers (mainly $\alpha$-olefins) or highly linear polyethylene depending on the steric properties of the $\mathrm{N}$-aryl groups. Subsequently, a second generation of catalysts incorporating both subtle and more dramatic changes to the parent $N, N, N$-bis(arylimino)pyridine framework have emerged that not only allow exceptional performance and high thermal stabilities but are also capable of promoting a broad range of oligomer and polymer properties [43,46,51]. While catalysts bearing the prototypical A (Figure 1) continue to see some important developments as symmetrical and unsymmetrical derivatives [43-51], the disclosure of carbocyclic-fused $N, N, N$-pincer ligands ( $\mathbf{B}$ and $\mathbf{C}$, Figure 1) represents a notable recent advance in the field $[43,46,51]$. In particular, the central pyridine donor of an $N, N, N$ ligand can be fused by either aryl or saturated cycloalkyl rings, the latter being amenable to their introduction as singly (B, Figure 1) or doubly (C, Figure 1) fused units with the alkyl ring sizes anywhere from five- to eight-membered $[43,46,51]$. The net effect of these ring variations is to influence the strain and chelation properties of the tridentate ligand which in-turn affects the catalytic performance, thermal robustness, polymer properties and oligomeric distributions.

\section{$<$ Figure 1 $>$}

In this review it is the objective to cover key developments in iron and cobalt catalyst technology that have occurred in the last decade with a focus on making correlations between pre-catalyst/ligand, co-catalyst, thermal stability and the microstructure of the 
resulting polymers and oligomers. For reviews and book chapters covering the first decade since the initial discovery of such catalysts, the reader is directed towards a number of leading references $[44,45,47-50]$.

\section{Fe/Co pre-catalysts bearing bis(arylimino)pyridines}

In 1998, the Brookhart [52] and Gibson [53,54] groups independently disclosed bis(arylimino)pyridine-iron and -cobalt pincer complexes as catalysts for ethylene oligo-/polymerization. These initial studies found that activation of $1(\mathrm{M}=\mathrm{Fe}, \mathrm{Co} ; \mathrm{X}=$ $\mathrm{Cl}, \mathrm{Br}$ ) (Figure 2), incorporating alkyl groups at the ortho- and para-positions of the $\mathrm{N}$-aryl groups, with methylalumoxane (MAO) $[53,54]$ or modified methylaluminoxane (MMAO) [52] resulted in high activity in ethylene polymerization (up to $206.0 \times 10^{6} \mathrm{~g}$ $\mathrm{PE} \mathrm{mol}{ }^{-1}(\mathrm{Fe}) \mathrm{h}^{-1}$ and $17.0 \times 10^{6} \mathrm{~g} \mathrm{PE} \mathrm{mol}^{-1}(\mathrm{Co}) \mathrm{h}^{-1}$ for $\mathrm{Ar}=2,4,6$-trimethylphenyl; reaction conditions: isobutane as solvent, 10 bar of ethylene, reaction time $1 \mathrm{~h}, 50^{\circ} \mathrm{C}$ ). More importantly, these catalysts promoted the formation of high density/highly linear polyethylene with high molecular weight $\left(M_{\mathrm{w}} \sim 10^{5} \mathrm{~g} \mathrm{~mol}^{-1}\right)$ [54]. By contrast, catalysts containing $\mathrm{N}$-aryl groups substituted by less bulky substituents at the ortho-positions (2, Figure 2) generated oligomers displaying Schulz-Flory distributions (with activities up to $10^{6} \mathrm{~g}$ (oligomer) $\mathrm{mmol}^{-1}(\mathrm{Fe}) \mathrm{h}^{-1}$ at $90{ }^{\circ} \mathrm{C}$ ) $[55,56]$.

\section{$<$ Figure 2 $>$}

In subsequent years considerable efforts have been devoted to modifying the bis(arylimino)pyridine pincer framework with the purpose of enhancing the catalytic activities and thermal stability of their complexes. These efforts have mainly concentrated on varying the substituents on the $\mathrm{N}$-aryl group with the aim to affect the steric hindrance and electronic properties of the complexes and in-turn the polymerization activities and polymer microstructure [43-51]. In addition, studies directed to modifying the imine-N and imine-C substituents as well as the central pyridine unit have seen some developments.

The Qian group in 2002 investigated the use of bis(arylimino)pyridine-iron and cobalt 
complexes 3 bearing 2,6-dihalide substituted $\mathrm{N}$-aryl groups (Figure 3) [57,58]. Examples bearing fluoride substituents exhibited by far the highest activity amongst this series while the fluoride-substituted iron complexes exhibited high selectivity ( $>93 \%)$ for linear $\alpha$-olefins $[57,58]$. On the other hand, derivatives bearing chloride or bromide substituents at both ortho-positions afforded relatively lower activities but produced highly linear polyethylene with high molecular weight $\left(\approx 10^{6} \mathrm{~g} \mathrm{~mol}^{-1}\right)$. Moreover, the introduction of iodide substituents led to increased activity [58].

\section{$<$ Figure 3 $>$}

The influence of the para-substituent on the $\mathrm{N}$-aryl rings in bis(arylimino)pyridine-iron complexes 4 (Figure 4) has been studied by the Alt group [59]. In the presence of MAO, the resultant catalysts can oligo-/polymerize ethylene to give highly linear products with the size and the electronegativity of the para-substituents playing an important role in determining activity [59]. (Table 1). For $\mathrm{Br}$ and I, both the size and the electronegativity of the substituents play an important role, while the size of the substituents was the decisive factor with the iodo derivatives giving higher polymerization activity $(14.6 \times$ $\left.10^{7} \mathrm{~g} \mathrm{PE} \mathrm{mol}^{-1}(\mathrm{Fe}) \mathrm{h}^{-1}\right)$ along with an increased content of higher molecular weight olefins $\left(M_{\mathrm{w}}=10.2 \times 10^{4} \mathrm{~g} \mathrm{~mol}^{-1}\right)($ entries 1-3, Table 1). By contrast, with more bulky alkynyl groups at the para-positions the molecular weight of the polymeric products was found to significantly increase (entry 4, Table 1) [59].

\section{$<$ Figure 4 $>$}

$<$ Table 1 $>$

\section{$<$ Figure 5 $>$}

The Alt group has also investigated the use of a series of bis(arylimino)pyridine-based iron complexes 5 in which the imine-carbon is linked to an $\omega$-alkenyl group (Figure 5) [60]. It was found that complexes containing two ortho-substituents on the $\mathrm{N}$-aryl rings only produced linear polyethylene with high molecular weight $\left(\sim 10^{6} \mathrm{~g} \mathrm{~mol}^{-1}\right)$ and broad molecular weight distributions with the highest activity (up to $51.9 \times 10^{6} \mathrm{~g} \mathrm{PE} \mathrm{mol}^{-1}(\mathrm{Fe}$ ) $\mathrm{h}^{-1}$ ) shown with MAO as co-catalyst. Conversely, with only one ortho-substituent on the $\mathrm{N}$-aryl rings, the complexes produced, depending on the bulk of the substituent, either 
mixtures of polymer and oligomer or solely oligomers [60].

\section{$<$ Figure 6 $>$}

Elsewhere, the Herrmann group explored a variety of iron complexes 6a-f (Figure 6) bearing symmetrical and unsymmetrical bis(arylimino)pyridines as pre-catalysts for the polymerization of ethylene and propylene using MMAO as activator [61]. 6b exhibited activities as high as $10^{7} \mathrm{~g} \mathrm{PE} \mathrm{mol}^{-1}(\mathrm{Fe}) \mathrm{h}^{-1}$ bar $^{-1}$ for ethylene polymerization while the activity for the oligomerization of propylene was far lower. In contrast, due to the introduction of bulky biphenyl groups, 6d showed very low activity for the polymerization of either ethylene or propylene [61]. The activity of the unsymmetrical pre-catalyst 6 e was found to be similar to symmetrical $\mathbf{6 b}$ and $\mathbf{6 c}$, viz. $8.0 \times 10^{7} \mathrm{~g} \mathrm{PE}$ $\mathrm{mol}^{-1}(\mathrm{Fe}) \mathrm{h}^{-1}$ bar $^{-1}$. The molecular weights of the polymeric materials were slightly higher for $\mathbf{6 e}$ than in the case of $\mathbf{6 b}$. However, use of $\mathbf{6 e}$ for propylene polymerization was less successful [61].

\section{$<$ Figure 7 $>$}

Ionkin and co-workers have explored the effect of a cyano group at the para-position of an $\mathrm{N}$-aryl group on the catalytic performance of bis(arylimino)pyridine iron(II) and iron(III) complexes 7 (Figure 7) [62]. Notably cyano-containing 7b maintained high activity even at $120^{\circ} \mathrm{C}$ and, what is more, produced $\alpha$-olefins with higher $\mathrm{K}$ values $[\mathrm{K}=$ rate $_{\text {propagation }} /\left(\right.$ rate $_{\text {propagation }}+$ rate $\left._{\text {chain transfer }}\right)=\left(\right.$ moles of $\left.C_{n+2}\right) /\left(\right.$ moles of $\left.\left.C_{n}\right)\right]$ in its Schulz-Flory distribution when compared with $\mathbf{7 c}$ and less of the heavier insoluble fractions of $\alpha$-olefins than observed for cyano-free 7a [62].

\section{$<$ Figure 8 $>$}

In addition, the Ionkin group has studied the influence of boryl-substitution in iron(II)-containing 8 on the production of $\alpha$-olefins (Figure 8) [63]. Notably, unsymmetrical 8a-c exhibited greater thermal stability but were less productive than symmetrical complex 7c (Figure 7); a more desirable product Schulz-Flory distribution was an added benefit of 8a-c [63].

\section{$<$ Figure 9 $>$}

The effect of chain length in N-alkenyl-substituted bis(arylimino)pyridine-iron and -cobalt complexes 9 was subject to an investigation by the Erker group (Figure 9) [64]. 
The results showed that when the N-substituent is an allyl group $(\mathrm{n}=1)$, the activity of the catalyzed oligomerization reaches a maximum of $4.7 \times 10^{6} \mathrm{~g} \mathrm{PE} \mathrm{mol}^{-1}(\mathrm{Fe}) \mathrm{h}^{-1}$ but decreases with an increase in the $\mathrm{CH}_{2}$ chain length [64].

\section{$<$ Figure 10 $>$}

The role played by substituents on the 4-position of the central pyridine ring on the catalytic performance of bis(arylimino)pyridine-iron and -cobalt complexes 10 [65] (Figure 10) has been studied by the Cámpora group. While the introduction of 4-alkyl groups generally increases the solubility of the complexes, the impact on the catalytic activity was rather limited. However, the polyethylene products exhibit higher molecular weight and broader molecular weight distributions. For example, GPC analyses of the polymers produced by $\mathbf{1 0 c}(\mathrm{Fe})$ revealed much higher values of $M_{\mathrm{w}}$ (up to $1.8 \times 10^{5} \mathrm{~g}$ $\left.\mathrm{mol}^{-1}\right)$ and a larger polydispersity index $(\mathrm{PDI}=21)$ than that observed by $\mathbf{1 0 a}(\mathrm{Fe})$ and $10 \mathrm{~b}(\mathrm{Fe})\left(M_{\mathrm{w}}\right.$ up to $\left.8.3 \times 10^{4} \mathrm{~g} \mathrm{~mol}^{-1}, \mathrm{PDI}=2.7-7.9\right)$. It has been suggested that this may be due to self-immobilization occurring via co-polymerization of the pendant alkenyl group in 10c [65].

\section{$<$ Figure 11 $>$}

Wu and co-workers have investigated the use of iron and cobalt complexes 11 (Figure 11) bearing para-nitro substituted 2,6-bis(2,6- $\mathrm{R}^{2}$-phenylimino)pyridines for ethylene polymerization [66]. It was observed that the iron-containing 11b exhibited increased catalytic activities $\left(6.00 \times 10^{6} \mathrm{~g} \mathrm{PE} \mathrm{mol}^{-1}(\mathrm{Fe}) \mathrm{h}^{-1} \mathrm{bar}^{-1}\right)$ relative to the protio-substituted counterpart 6a $\left(4.80 \times 10^{6} \mathrm{~g} \mathrm{PE} \mathrm{mol}^{-1}(\mathrm{Fe}) \mathrm{h}^{-1}\right.$ bar $\left.^{-1}\right)$. This was attributed to the strong electron-withdrawing properties of the nitro groups leading to an increased Lewis acidic character at the cationic iron center in the active species. The steric properties of the ortho group in such iron catalytic systems also played a significant role in controlling the catalyst activity and mass of the polymer as exemplified by $\mathbf{1 1 a}\left(\mathrm{R}^{1}=\mathrm{Me}\right)$ which showed much lower polymerization activities than the ortho-isopropyl analog 11b [66].

\section{$<$ Figure 12 $>$}

Xie et. al. focused on the unsymmetrical bis(arylimino)pyridine-iron complexes $\mathbf{1 2}$ (Figure 12), containing alkyl and halide substituents, and their effect on ethylene oligomerization. The catalytic activities of $12\left(\mathrm{R}^{1}=\mathrm{Me}, \mathrm{R}^{2}=\mathrm{H}, \mathrm{X}^{1}=\mathrm{F}\right.$ or $\mathrm{Cl}, \mathrm{X}^{2}=\mathrm{X}^{3}=$ 
$\mathrm{H})$, using MMAO as co-catalyst, can exceed $10^{6} \mathrm{~g} \mathrm{~mol}^{-1}(\mathrm{Fe}) \mathrm{h}^{-1} \mathrm{bar}^{-1}$, which is higher than that of the Me- or F-substituted symmetric 2,6-bis(arylimino)pyridine-iron(II) complexes [67]. The products obtained were mainly linear $\alpha$-olefins (up to 98\%) with the distribution falling between $\mathrm{C}_{4}$ and $\mathrm{C}_{24}$; no polymer products were detected. The catalytic performance, especially the oligomer distribution, could be tuned by synergistic steric and electronic effects. Electron withdrawing halide groups could also exert an influence on the catalytic behavior of unsymmetrical bis(arylimino)pyridine-substituted iron complexes, such that ligands containing halide substituents enhanced the catalytic performance $[67,68]$.

In order to improve the thermal stability of late transition metal pre-catalysts, considerable efforts have been directed towards devising means to address this performance limitation. In particular, the introduction of more sterically bulky $\mathrm{N}$-aryl groups to the bis(arylimino)pyridine ligand frame have been the subject of multiple reports and indeed this modification has produced some very encouraging results [43-51].

\section{$<$ Figure 13 $>$}

The Wu group has studied the use of three iron complexes 13a-c (Figure 13) containing bulky $\mathrm{N}$-aryl groups for ethylene polymerization [69]. In the presence of MAO, complex 13b $\left(\mathrm{R}^{1}=\mathrm{Me}\right)$, containing an N-2,4-dimethyl-6-sec-phenethyl group, exhibited a better activity and produced much higher molecular weight $\left(M_{\mathrm{w}} \sim 1.2 \times 10^{6} \mathrm{~g} \mathrm{~mol}^{-1}\right)$ polyethylene than that observed using the singly ortho-substituted analogs 13a and 13c $\left(\mathrm{R}^{1}=\mathrm{H}\right)$ as well as the well-documented symmetrical 2,6-diisopropylphenyl-substituted complex 6a [69]. More importantly, even at $70{ }^{\circ} \mathrm{C}$, pre-catalyst $\mathbf{1 3 b}$ maintained a high activity and displayed relatively stable kinetics although leading to the formation of products of lower molecular weight at elevated temperature $\left(M_{\mathrm{w}}=2.3 \times 10^{4} \mathrm{~g} \mathrm{~mol}^{-1}\right.$ at $\left.70{ }^{\circ} \mathrm{C}\right)$. All the products were linear polyethylenes displaying bimodal or broad molecular weight distributions, which was attributed to the co-existence of two chain transfer pathways. The amount of the low molecular weight fraction increased on increasing the $\mathrm{Al} / \mathrm{Fe}$ ratio [69]. 
Over the last five years, our group has also been interested in improving the catalytic activity and thermal stability of bis(arylimino)pyridine-iron and -cobalt complexes $[43,46,51]$. In particular we have found that the introduction of sterically demanding benzhydryl groups and their derivatives into the $N, N, N$-ligand frame of their iron and cobalt catalysts can be influential (14-30, Figure 14) [70-81]. For example, iron-containing 14 [70], 16 [72,73], 21 [75], 23 [77], 25 [77], 27 [78], 29 [80] (Figure 14, $\left.\mathrm{R}^{1}=\mathrm{Me}, \mathrm{Et}, i-\mathrm{Pr}, \mathrm{R}^{2}=\mathrm{H}, \mathrm{Me}\right)$ all showed outstanding catalytic activity in the order of $10^{7} \mathrm{~g} \mathrm{PE} \mathrm{mol}^{-1}(\mathrm{Fe}) \mathrm{h}^{-1}$ and good thermal stability (maintained high activity at over $60{ }^{\circ} \mathrm{C}$ ) for ethylene polymerization (see Table 2).

\section{$<$ Figure 14 $>$}

With regard to 14, 16 and 21 (Figure 14), activation with either MAO or MMAO resulted in high activity producing polyethylene of moderate $M_{\mathrm{w}}\left(12-340 \mathrm{~kg} \mathrm{~mol}^{-1}\right)$ without any trace of oligomeric species $[70,72,73]$. When the para- $\mathrm{R}$ group is $\mathrm{Me}$, the iron pre-catalysts 14a (Figure 14) in combination with MMAO exhibited high activity up to $22.4 \times 10^{6} \mathrm{~g} \mathrm{PE} \mathrm{mol}{ }^{-1}(\mathrm{Fe}) \mathrm{h}^{-1}$ at $80{ }^{\circ} \mathrm{C}$ and the products were all strictly linear polyethylene with broad molecular weight distributions [70]. When the para-R group is $\mathrm{Cl}$, with the same co-catalyst, 16b (Figure 14) showed higher activities (up to $24.6 \times 10^{6}$ $\mathrm{g} \mathrm{PE} \mathrm{mol}^{-1}(\mathrm{Fe}) \mathrm{h}^{-1}$ ) for ethylene polymerization than analog 14 at $60{ }^{\circ} \mathrm{C}$. Furthermore, the polyethylene generated showed higher molecular weight $\left(M_{\mathrm{w}}=42.0 \mathrm{~kg} \mathrm{~mol}^{-1}\right)$ than that seen by $14\left(M_{\mathrm{w}}=25.5 \mathrm{~kg} \mathrm{~mol}^{-1}\right)$ (see Table 2) [72,73]. By stark contrast, the symmetrical iron complexes $\mathbf{1 8}$ and $\mathbf{2 0}$ (Figure 14) bearing two bulky 2,6-dibenzhydrylphenyl groups showed only poor activity with only trace amounts of polymers detectable which has been credited to the presence of too much steric bulk $[70,72,73]$. Meanwhile, a family of unsymmetrical diphenylmethyl-containing bis(arylimino)pyridine-iron and -cobalt complexes 21 and 22 (Figure 14) still displayed high activity and thermal stability for ethylene catalysis [75,76]. On treatment with either MAO or MMAO, all the iron pre-catalysts possessed good thermo-stability and exhibited high activities (up to $22.7 \times 10^{6} \mathrm{~g} \mathrm{PE} \mathrm{mol}^{-1}(\mathrm{Fe}) \mathrm{h}^{-1}$ ) towards ethylene polymerization, producing highly linear polyethylene [75]. 
Our group has also studied several kinds of bis(arylimino)pyridine-iron and -cobalt complexes 23-26 (Fig 14) bearing only one ortho-substituted diphenylmethyl group. High catalytic activity of up to $15.7 \times 10^{6} \mathrm{~g} \mathrm{PE} \mathrm{mol}^{-1}(\mathrm{Fe}) \mathrm{h}^{-1}$ in the presence of either MAO or MMAO (Table 2) [77] was observable. The iron pre-catalysts $\mathbf{2 3}$ and $\mathbf{2 5}$ show much higher activity than their cobalt analogs 24 and 26 (up to $3.2 \times 10^{6} \mathrm{~g} \mathrm{PE} \mathrm{mol}^{-1}$ (Co) $\mathrm{h}^{-1}$ ), while the iron systems generally produced polyethylene of broad molecular weight distribution [41]. In comparison with the dibenzhydryl-containing iron pre-catalysts $\mathbf{1 4}$, 16 and 21 (Figure 14) [70,72,75], 23 and 25 displayed relatively lower activity in the presence of either MAO or MMAO, indicating that dibenzhydryl-substituted N-aryl groups enhanced the catalytic performance of their metal complexes [77].

\section{$<$ Table 2 $>$}

With an eye to balancing high thermal stability with high activity in bis(arylimino)pyridine-iron and -cobalt catalysts, 27-30 (Figure 14) containing bulky unsymmetrical $N, N, N$-tridentate bis(arylimino)pyridines in which difluorobenzhydryl groups have been appended to the ortho-/para-positions, have been investigated [78-80]. On activation with MMAO, all these iron and cobalt complexes displayed high activities towards ethylene polymerization at $60{ }^{\circ} \mathrm{C}$, with the cobalt examples generally showing a slightly lower activity (up to $7.6 \times 10^{6} \mathrm{~g} \mathrm{PE} \mathrm{mol}^{-1}(\mathrm{Co}) \mathrm{h}^{-1}$ in $15 \mathrm{~min}$ for 28 ) than their iron analogs (up to $3.5 \times 10^{7} \mathrm{~g} \mathrm{PE} \mathrm{mol}^{-1}(\mathrm{Fe}) \mathrm{h}^{-1}$ in $15 \mathrm{~min}$ for 27 ). Comparison of $27(\mathrm{Fe})$ and 28 (Co), containing two ortho-substituted difluorobenzhydryl groups [78,79], with $29(\mathrm{Fe})$ and $30(\mathrm{Co})$ based on a 2,4-substitution pattern, a relatively lower activity (up to $2.0 \times 10^{7} \mathrm{~g} \mathrm{PE} \mathrm{mol}^{-1}(\mathrm{Fe}) \mathrm{h}^{-1}$ for 29; $3.7 \times 10^{6} \mathrm{~g} \mathrm{PE} \mathrm{mol}^{-1}(\mathrm{Co}) \mathrm{h}^{-1}$ for 30) was shown when using either MAO or MMAO as activator [78-80]. Recently, bis(arylimino)pyridine-iron complexes $\mathbf{3 1}$ (Figure 14) containing the benzhydrylnaphthyl group have been shown to exhibit slightly higher activities (up to $8.5 \times 10^{6} \mathrm{~g} \mathrm{PE} \mathrm{mol}^{-1}(\mathrm{Fe}) \mathrm{h}^{-1}$ ) and better thermal stability at elevated temperatures (up to $80{ }^{\circ} \mathrm{C}$ ) with MMAO as co-catalyst [81]. Using cobalt in place of iron, the catalytic activities for ethylene polymerization of $15,17,22,24,26,28$ and 30 were shown to be one order of magnitude lower (Table 2) than the corresponding iron pre-catalysts [71-80]. 
In addition, polymers obtained via the cobalt-containing 15, 17, 22, 24, 26, 28 and 30

(Table 2) possessed narrower molecular weight distributions, indicative of a single-site active species $[71,74,76,77,79,80]$.

\section{Aryl-fused $N, N, N$-ligands and their $\mathrm{Fe} / \mathrm{Co}$ pre-catalysts}

While changes to the parent bis(arylimino)pyridine ligand structure have led the way $[43,46,51]$ in the quest for higher catalytic activity, better thermal stability and more control of the polymer microstructure, the emergence of more significant modifications to the $N, N, N$ framework have been reported.

\section{$<$ Figure 15 $>$}

Around 2002, our group investigated the use of a series of $N, N, N$-bearing late transition metal complexes ligated by 2,9-bis(arylimino)-1,10-phenanthroline ligands for oligomerization and/or polymerization [82]. The cobalt complexes 33 (Figure 15) showed high to good catalytic activities for ethylene oligomerization, but the iron complexes 32 (Figure 15) showed only low activities for ethylene polymerization. The latter observation was ascribed to the detrimental coordination of the additional imino group to the metal ( $\mathrm{Fe}$ or $\mathrm{Co}$ ) center during propagation thereby impeding ethylene coordination and thus decreasing the catalytic activity [82]. The same result was also reported by Gibson's group [83]. Given this undesirable coordination, 2-imino-1,10-phenanthroline derivatives and their iron and cobalt complexes 34-37 (Figure 15) were reported by our lab for the first time in 2006 [84-87]. Independently, the Solan group was also aware of the beneficial properties of 2-imino-1,10-phenanthrolines in late transition metal catalysis and reported their findings on cobalt in 2006 [88]. As expected, the iron complexes $34\left(\mathrm{R}=\mathrm{Me}, \mathrm{R}^{1}=\mathrm{Et}\right.$, $\mathrm{R}^{2}=\mathrm{H}$ ) exhibited the highest activity (up to $4.91 \times 10^{7} \mathrm{~g} \mathrm{~mol}^{-1}(\mathrm{Fe}) \mathrm{h}^{-1}$ ) for ethylene oligomerization among its analogs 35-37, and with high selectivity for $\alpha$-olefins ( $>94 \%$ ) (Table 3) with oligomers displaying Schulz-Flory distributions [48-51]. Of particular note, iron-containing 34b $\left(R=M e, R^{1}=E t, R^{2}=H\right)$ has been used in a 500 ton per year pilot process for making $\alpha$-olefins $[46,84,85]$. 
In addition, it was found that the ortho-substituents on the $\mathrm{N}$-aryl group in iron-containing 34 (Figure 15) affected the activity and the nature of the hydrocarbon product formed. For example, with ortho-Et substituents, 34b $\left(R=M e, R^{1}=E t, R^{2}=H\right)$ afforded the highest activity, while electron withdrawing ortho-substituents such as halides decreased the ethylene reactivity $(\mathrm{Br}>\mathrm{Cl}>\mathrm{F})$ [84]. Meanwhile, variation of the $\mathrm{R}$ substituent on the imino- $\mathrm{C}$ of the ligands, $2-(\mathrm{ArN}=\mathrm{CR})-1,10$-phenanthroline, also resulted in changes to the catalytic performance. The aldimine $(\mathrm{R}=\mathrm{H}, \mathbf{3 4 a})$, phenyl-ketimine $(\mathrm{R}=\mathrm{Ph}, \mathbf{3 4 c})$ and ethyl-ketimine $(\mathrm{R}=\mathrm{Et}, \mathbf{3 4 d})$ 1,10-phenanthroline-iron complexes showed relatively lower catalytic activities than was observed for 34b $(\mathrm{R}=\mathrm{Me})$ (Table 3) [84-87]. All the oligomers exhibited Schulz-Flory distributions. Interestingly, when compared with their analogs 34a-c $[48,49]$, 34d containing an ethyl substituent on the imino-C showed better thermal stability $\left(10^{\circ} \mathrm{C}\right.$ higher when compared to $\mathbf{3 4 b}$, Table 3$)$ with either MAO or MMAO as co-catalyst and displayed a higher content of $\alpha$-olefins $\left(\mathrm{C}_{6}-\mathrm{C}_{16}\right)$ and a lower content of $\mathrm{C}_{4}$ [86]. However, when a phenyl-substituted group was introduced at the 9-position of the 1,10-phenanthroline [59], the corresponding iron complexes 36a-b (Figure 15 and Table 3) showed much lower activities $\left[1.9 \times 10^{6} \mathrm{~g} \mathrm{~mol}^{-1}(\mathrm{Fe}) \mathrm{h}^{-1}\right.$, Table 3] when compared to $34 \mathbf{a}-\mathbf{d}$ ( $\mathrm{ca} .1 / 25^{\text {th }}$ of that seen for $\mathbf{3 4 d}$ ). In addition, the products contained much higher amounts of the short chain $\mathrm{C}_{4}$ (major product, $>90 \%$ ) and $\mathrm{C}_{6}$ fractions and no evidence for polymer formation $[48,49,53]$. Replacement of the imine group with benzimidazoles resulted in iron and cobalt $\mathbf{3 8}$ and 39 bound by 2-(benzimidazol-2-yl)-1,10-phenanthrolines. All these complexes exhibited good to high catalytic activities toward ethylene oligomerization with MMAO as activator and showed good selectivity for $\alpha$-olefins (mainly $\mathrm{C}_{4}$ and $\mathrm{C}_{6}$ ) [90]. On the other hand, the introduction of a methyl group at the 9-position of the phenanthroline moiety led to a decrease in oligomerization activity and a slight increase in the $\alpha-\mathrm{C}_{4}$ selectivity [54]. Replacing the imidazole group by a 2-benzoxazole or an oxazoline, the corresponding iron and cobalt complexes 40-43 (Figure 15) displayed much lower activity with the resulting oligomers composed mainly of 1-butene and 1-hexene while the $\alpha$-C4 selectivity was lower [91]. Once again, when using cobalt instead of iron, the catalytic 
activity for ethylene oligomerization of the pre-catalysts $33,35,37,39,41$ and 43 was lower than the corresponding iron pre-catalysts [82,87-91].

$<$ Figure 16 $>$

Our group has also studied the catalytic behavior of iron and cobalt complexes 44-50 (Figure 16) containing alternative aryl-fused $N, N, N$ ligand sets for ethylene oligo-/polymerization [92-98]. Iron-containing 44 (Figure 16), bearing a 2-quinoxalinyl-6-iminopyridine, showed in the presence of MAO high activity $(1.2 \times$ $\left.10^{6} \mathrm{~g} \mathrm{~mol}^{-1}(\mathrm{Fe}) \mathrm{h}^{-1}\right)$ for ethylene oligomerization with $\mathrm{C}_{4}$ as the major product $(\sim 95 \%)$ at atmospheric pressure [92]. On the other hand, their cobalt counterparts, $\mathbf{4 5}$, showed only moderate activities toward ethylene oligomerization with MMAO as co-catalyst. For example, the catalytic activity of 45 (Figure 16) was $1.67 \times 10^{5} \mathrm{~g} \mathrm{~mol}^{-1}(\mathrm{Co}) \mathrm{h}^{-1}$ for oligomerization and the $\mathrm{C}_{4}$ percentage was $96 \%$. Both the activity and the content of the longer-chain oligomers was enhanced with increasing ethylene pressure [92]. In addition, for iron-based 44, mixtures of oligomers and polyethylene waxes were in some cases yielded with overall good activity (up to $8.56 \times 10^{5} \mathrm{~g} \mathrm{~mol}^{-1} \mathrm{Fe} \mathrm{h}^{-1}$ for polymerization and $2.24 \times 10^{6} \mathrm{~g} \mathrm{~mol}^{-1}(\mathrm{Fe}) \mathrm{h}^{-1}$ for oligomerization) [92]. Elsewhere, iron and cobalt 46-48 (Figure 16) containing 2-(2-benzimidazolyl)-6-(1-(arylimino)ethyl)pyridines have also been reported, all of which revealed high activity (up to $4.11 \times 10^{6} \mathrm{~g} \mathrm{~mol}^{-1}(\mathrm{Fe}) \mathrm{h}^{-1}$ ) towards ethylene oligomerization; some formation of polyethylene waxes was also evident (see Table 4) [93-95].

\section{$<$ Table 4 $>$}

The order of activity follows $46 \mathbf{a}(\mathrm{R}=\mathrm{H})[93]>\mathbf{4 6 b}(\mathrm{R}=\mathrm{Me})[94]>\mathbf{4 6} \mathbf{c}(\mathrm{R}=i$-Pr) $[95]$ (Table 4) and was attributed to the electronic influences imparted by the R substituents. The iron pre-catalysts $\mathbf{4 6 b}-\mathbf{c}$ showed good to moderate catalytic activity $(0.86-1.20 \times$ $10^{6} \mathrm{~g} \mathrm{~mol}^{-1}(\mathrm{Fe}) \mathrm{h}^{-1}$, Table 4) for ethylene oligo-/polymerization [94, 95]. The resultant oligomer and polyethylene waxes were composed of $\alpha$-olefins and the oligomers were shown to follow a Schulz-Flory distribution with some exceptions [94, 95. Furthermore, the order of activity $46 \mathbf{a}(\mathrm{R}=\mathrm{H})[93]>\mathbf{4 8 a}(\mathrm{R}=\mathrm{Me})[96]>\mathbf{4 8 b}(\mathrm{R}=\mathrm{Cl})[96]($ Table 4$)$ highlights the role played by steric effects $[93,96]$. The iron complexes 48a-b bearing 2-(R-1H-benzoimidazol-2-yl)-6-(1-aryliminoethyl)pyridine derivatives gave high 
activities (up to $3.03 \times 10^{6} \mathrm{~g} \mathrm{~mol}^{-1}(\mathrm{Fe}) \mathrm{h}^{-1}$ ) for ethylene oligomerization (Table 4). All oligomers produced were in the range of $\mathrm{C}_{4}-\mathrm{C}_{28}$ with very high selectivity for linear $\alpha$-olefins and high $\mathrm{K}$ values with no evidence of polymeric products detectable [96]. The 2-( $\beta$-benzothiazolyl)-6-[1-(arylimino)ethyl]pyridine-iron complexes 50 (Fig 16, Table 4), showed good activity up to $10^{7} \mathrm{~g} \mathrm{~mol}^{-1}(\mathrm{Fe}) \mathrm{h}^{-1}$ for ethylene oligo-/polymerization, with high selectivity for vinyl-terminated oligomers or polyethylene waxes [98]. By contrast, their cobalt analogs 47, 49 and 51 (Fig 16) showed lower ethylene reactivity than the iron complexes 46, 48 and $\mathbf{5 0}[93-95,97,98]$.

\section{$<$ Figure 17 $>$}

Gibson et al. investigated the use of iron complex 51 (Figure 17) bearing 6-aryliminoethyl-2,2'-bipyridine as the $N, N, N$-ligand for ethylene oligomerization $[83,99]$. All these complexes showed low activity of $5.70 \times 10^{6} \mathrm{~g} \mathrm{~mol}^{-1}(\mathrm{Fe}) \mathrm{h}^{-1}$ and produced very low molecular weight oligomers [83]. It was suggested that the "in-plane" steric crowding at the iron center by the terminal pyridine ring slowed down the coordination and insertion of ethylene in 51 [83]. Subsequently, the Yasuda group screened the catalytic behavior of iron complexes $\mathbf{5 2}$ (Figure 17) chelated by the tri-pyridine derivatives for olefin polymerization [100]. Notably, 52 showed activities for 1,2/3,4-polymerizations of isoprene and trans-1,4-polymerization of 1,3-butadiene ranging from moderate to high in the presence of MMAO as co-catalyst [100]. The iron and cobalt pre-catalysts $\mathbf{5 3}$ containing $\mathrm{N}$-aryl-functionalized 2,6-bis[3(5)-pyrazolyl]pyridines (Figure 17) showed low activity $\left(4.0 \times 10^{6} \mathrm{~g} \mathrm{~mol}^{-1}(\mathrm{Fe})\right.$ $\mathrm{h}^{-1}$ ) for ethylene polymerization and gave highly linear polyethylene with high molecular weight [101]. Concurrently, the iron and cobalt complexes 54 (Figure 17) bearing bis(pyrazolyl)pyridine derivatives revealed some activity $\left(2.0-9.7 \times 10^{6} \mathrm{~g} \mathrm{~mol}^{-1}\right.$ $\left.(\mathrm{Fe} / \mathrm{Co}) \mathrm{h}^{-1}\right)$ producing polyethylene of high molecular weight $\left(2.6-3.5 \times 10^{5} \mathrm{~g} \mathrm{~mol}^{-1}\right)$, particularly those possessing a methylene group positioned between the pyrazolyl and pyridine rings [102,103]. The Tenza group has also studied the catalytic behavior of bis(imidazole)/(carbene)pyridine-iron complexes for ethylene polymerization [104]. Symmetric iron complex 55 (Figure 17) exhibited lower activity $\left(1.3 \times 10^{3} \mathrm{~g} \mathrm{~mol}^{-1}(\mathrm{Fe})\right.$ $\mathrm{h}^{-1}$ ) than its asymmetric analog $46[93,94,104]$. Bis(oxazoline)pyridine-iron complexes 
56 also showed very low activity $\left(1.1 \times 10^{3} \mathrm{~g} \mathrm{~mol}^{-1}(\mathrm{Fe}) \mathrm{h}^{-1}\right)$ toward ethylene [105].

\section{Cycloalkyl-fused bis(arylimino)pyridines and their $\mathrm{Fe} / \mathrm{Co}$ pre-catalysts}

During the last five years or so, we have been interested in the effect of ring strain on the performance of nickel catalysts for ethylene polymerization [106]. In general, the ligand design has involved the fusion of cycloalkyl groups to a pyridyl-imine ligand to form new chelating $N, N$-ligands with variable binding capacity depending on the ring size of the cyclolalkyl unit [e.g. 8-arylimino-5,6,7-tetrahydroquinoline D (Fig 18)]. Indeed, the resultant catalysts have shown high activities and correlations between ring strain and catalyst performance/polymer properties have become evident [106-110]. Inspired by these results, we have been attracted by applying a similar strategy to the modification of bis(arylimino)pyridines (A in Figure 18) and have successfully formed $N, N, N$ ligands of the type 2-(1-(arylimino)ethyl)-8-arylimino-5,6,7-trihydroquine (B, Figure 18), in which a cyclohexyl unit is fused to one side of the pyridine $[111,112]$. As an extension to this approach, our group has developed a series of iron and cobalt complexes 57-63 (Figure 19) and 65-69 (Figure 20) bound by a host of new pyridine-based $N, N, N$ ligands containing singly or doubly fused units with the alkyl ring sizes anywhere from five- to seven [111-117,119-121]. In comparison with catalysts bearing the parent $N, N, N$-bis(arylimino)pyridine framework, these second generation iron and cobalt complexes have displayed exceptional performances for ethylene oligo-/polymerization, superior thermal stabilities and promote the formation of polyethylenes with a range of unusual properties $[43,46,51]$.

\section{$<$ Figure 18 $>$ \\ $<$ Figure 19>}

The iron and cobalt pre-catalysts 57 and 58 (Figure 19) bearing 2-(1-aryl imino)methyl-8-arylimino-5,6,7-tetrahydroquinolines, incorporating a six-membered ring, exhibited high activities and good thermal stability for ethylene polymerization with only polyethylenes isolable [111,112]. For iron-containing 57, all complexes

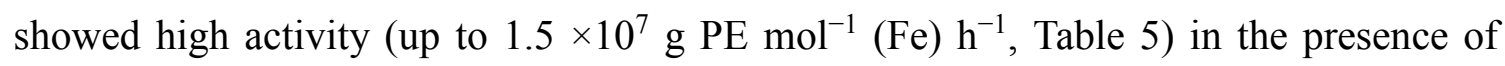
$\mathrm{MAO}$ at $50{ }^{\circ} \mathrm{C}$ generating highly linear polyethylene with moderate molecular weight 
$\left(2.2 \times 10^{4} \mathrm{~g} \mathrm{~mol}^{-1}\right.$, Table 5) and bimodal molecular weight distributions [111]. With regard to their cobalt analogs $\mathbf{5 8}$, high activities (up to $1.1 \times 10^{7} \mathrm{~g} \mathrm{PE} \mathrm{mol}^{-1}(\mathrm{Co}) \mathrm{h}^{-1}$, Table 6) and better thermal stability (the optimal operational temperature is $60{ }^{\circ} \mathrm{C}$, Table 6) were observable when compared to the prototypical 2,6-bis(arylimino)pyridine-cobalt complex 1 [53,54] (Figure 2), while the resultant polyethylenes showed lower molecular weight (waxes, $\sim 10^{3} \mathrm{~g} \mathrm{~mol}^{-1}$ ) with narrower PDI's (1.5) [112]. Chain-end analysis of all the polymers generated using $\mathbf{5 7}$ and $\mathbf{5 8}$ revealed the presence of saturated alkyl groups $[111,112]$. On the other hand, cobalt complexes 59 [113] bearing 2-(1-(arylimino)ethyl)-7-arylimino-6,6-dimethylcyclopenta[b]pyridines (Figure 19), containing a smaller five-membered cyclopentyl ring, showed much lower activities on activation with MAO $\left(2.89 \times 10^{4} \mathrm{~g} \mathrm{PE} \mathrm{mol}^{-1}(\mathrm{Co}) \mathrm{h}^{-1}\right.$, Table 6) than seen for 58 [112], and the polyethylene obtained was of higher molecular weight $\left(\sim 10^{5} \mathrm{~g} \mathrm{~mol}^{-1}\right.$, Table 6$)$ [113]. On activation with MMAO, 59 exhibited moderate activity $\left(3.6 \times 10^{5} \mathrm{~g} \mathrm{~mol}^{-1}(\mathrm{Co})\right.$ $\mathrm{h}^{-1}$ ) towards ethylene oligomerization and the oligomers obtained displayed Schulz-Flory distributions as characterized by the constant K [113]. Their variation in catalytic performance may be due to the weak bonding between cobalt and the imino-nitrogen linked to the pyridyl-fused cyclopentane. Even though the cobalt complexes 59 developed are not great catalysts for ethylene, they do nevertheless provide new concepts for ethylene polymerization research [113]. Pre-catalysts incorporating seven-membered rings, 60-63 (Figure 19), have also been prepared and screened for ethylene polymerization [114-117]. Either 2-(1-aryliminoethyl)-9-arylimino-5,6,7,8-tetrahydrocycloheptapyridyl-iron(II) chlorides 60 or 2-(arylimino)benzylidene-9-arylimino-5,6,7,8-tetrahydrocyclohepta-[b]pyridine -iron(II) chlorides 62, showed high activities (up to $1.5 \times 10^{7} \mathrm{~g} \mathrm{PE} \mathrm{mol}^{-1}(\mathrm{Fe}) \mathrm{h}^{-1}$, Table 5) $[114,115]$. The polyethylene obtained with $\mathbf{6 0}$ showed a narrower molecular weight distribution than the corresponding polyethylene generated with $\mathbf{6 2}$, while 62 showed increased thermal stability (optimal run temperature at $70^{\circ} \mathrm{C}$ ) and longer lifetime than their iron analogs 57 and $\mathbf{6 0}[111,114,115]$. Interestingly, their cobalt analogues $\mathbf{6 1}$ and 63 (Figure 19) also displayed high activities $\left(8.6 \times 10^{6} \mathrm{~g} \mathrm{PE} \mathrm{mol}^{-1}(\mathrm{Co}) \mathrm{h}^{-1}\right.$, Table 6) for ethylene polymerization and the resultant highly linear polyethylene waxes $\left(\sim 10^{3} \mathrm{~g} \mathrm{~mol}^{-1}\right)$ 
were shown to possess vinyl chain-ends [116,117]. Notably, such unsaturated polymers have some demand in the manufacture of long-chain branched copolymers, functional polymers as well as coating materials [118].

$<$ Figure 20 $>$

Besides our group, other research teams have appreciated the compatibility of these fused $N, N, N$ ligand sets for supporting potent iron and cobalt catalysts [119]. For example, doubly cycloalkyl-fused bis(arylimino)pyridine-iron and -cobalt complexes 64 and 65 (Figure 20) bearing 1,8-diimino-2,3,4,5,6,7-hexahydroacridines, have been reported by Kim et al.. Notably, these complexes exhibited high activities $\left(3.6 \times 10^{6} \mathrm{~g}\right.$ $\mathrm{PE} \mathrm{mol}^{-1}(\mathrm{Fe}) \mathrm{h}^{-1}$ bar $^{-1}$ and $2.9 \times 10^{6} \mathrm{~g} \mathrm{PE} \mathrm{mol}^{-1}(\mathrm{Co}) \mathrm{h}^{-1}$ bar $\left.^{-1}\right)$ for ethylene oligo-/polymerization [119]. However, one drawback with these catalysts is that their polyethylenes and oligomers can sometimes be formed as mixtures and hence limiting their interest in commercial applications.

\section{$<$ Table 5 $>$}

With the intent to obtain solely polymer or oligomer as the unique product from the catalytic run, the $\alpha, \alpha^{\prime}$-bis(arylimino)-2,3:5,6-bis(pentamethylene)pyridine-iron and -cobalt complex pre-catalysts 66 and 67 (Figure 20) were developed in our lab [120,121]. Indeed, iron-containing 66, exhibited very high activities in the range of $10^{7} \mathrm{PE} \mathrm{mol}{ }^{-1}$ (Fe) $\mathrm{h}^{-1}$ toward ethylene polymerization forming highly linear polyethylenes. Moreover, the polymeric materials showed vinyl end-groups $\left(-\mathrm{CH}=\mathrm{CH}_{2}\right)$ generated through $\beta$-hydride elimination as the termination process [84]. On the other hand, the cobalt analogs 67 exhibited lower activities $\left(3.69 \times 10^{6} \mathrm{~g} \mathrm{PE} \mathrm{mol}^{-1}(\mathrm{Co}) \mathrm{h}^{-1}\right)$ than 66 but still produced highly linear polyethylenes with low molecular weights $\left(\sim 10^{3} \mathrm{~g} \mathrm{~mol}^{-1}\right)$ and narrow PDI's (ca. 2.1) [121].

Most recently, we have also studied the catalytic behavior of a series of $\alpha, \alpha^{\prime}$-bis(arylimino)-2,3:5,6-bis(hexamethylene)pyridine-cobalt pre-catalysts 68 (Fig. 20), containing doubly-fused eight-membered rings in ethylene polymerization [122]. These cobalt complexes $\mathbf{6 8}$, in the presence of MMAO, showed high activity $\left(3.62 \times 10^{6} \mathrm{~g} \mathrm{PE}\right.$ $\left.\mathrm{mol}^{-1}(\mathrm{Co}) \mathrm{h}^{-1}\right)$ in ethylene polymerization and indeed similar to their cobalt analogs 67. Conversely, pre-catalysts $\mathbf{6 8}$ with MAO as activator showed slightly lower activity (2.89 
$\left.\times 10^{6} \mathrm{~g} \mathrm{PE} \mathrm{mol}^{-1}(\mathrm{Co}) \mathrm{h}^{-1}\right)$ than MMAO as co-catalyst [122]. Interestingly, the nature of the co-catalyst employed had a dramatic effect on the molecular weight of the polymeric material obtained. For example, using cobalt complexes in combination with MAO as co-catalyst gave high density and high molecular weight polyethylene $\left(M_{\mathrm{w}} \approx 10^{5} \mathrm{~g} \mathrm{~mol}^{-1}\right)$ with narrow MWD (2.1 - 3.6). By contrast, using MMAO, strictly linear polyethylene of relatively moderate molecular weight $\left(M_{\mathrm{w}} \approx 10^{4} \mathrm{~g} \mathrm{~mol}^{-1}\right)$ and broader MWD $(10.1-23.8)$ was obtained [122].

\section{$<$ Table 6 $>$}

To allow a comparison of the activities of the various cycloalkyl ring-fused iron and cobalt pre-catalysts (57-68; all activated with MAO) as well as the properties exhibited by their resultant polyethylenes (Figs. 19 and 20), the corresponding data has been collected in Tables 5 and 6. On inspection of the results, the polyethylenes obtained with catalysts containing either singly- or doubly-fused units based on seven-membered rings, viz., 61, 63 and 66 (Figs. 19 and 20), display in each case vinyl functional groups as one end of the chain $[116,117,120]$. As a representative example, the ${ }^{1} \mathrm{H}$ NMR spectrum (Figure 21) obtained using 63 reveals a downfield multiplet at $5.85 \mathrm{ppm}$ and an apparent triplet at $5.03 \mathrm{ppm}$, consistent with a 1-olefinic unit. This is complemented by the ${ }^{13} \mathrm{C}$ NMR spectrum (Figure 22) which reveals two single peaks between 140-110 ppm in agreement with the presence of a vinyl-group as a chain-end. In addition, both the ${ }^{1} \mathrm{H}$ NMR and ${ }^{13} \mathrm{C}$ NMR spectra confirm that the polyethylene samples were strictly linear $[116,117,120]$.

$<$ Figure 21 $>$

$<$ Figure 22 $>$

While further research into cycloalkyl-fused bis(arylimino)pyridine-iron and -cobalt complexes as catalysts for alkene polymerization looks set to continue, similar structural modifications can also be made to ketone-containing pyridylimines. For example, the iron and cobalt complexes 69 and 70 (Figure 23) bearing the $N, N, O$ ligand incorporating a fused cycloheptyl unit have been evaluated as catalysts in ethylene oligo-/polymerization [112]. On activation with MAO or MMAO, 70 exhibited good activities (up to $2.2 \times 10^{5} \mathrm{~g} \mathrm{~mol}^{-1}(\mathrm{Co}) \mathrm{h}^{-1}$ ) affording short chain oligomers $\left(\mathrm{C}_{4}-\mathrm{C}_{30}\right.$ ) 
with good $\alpha$-olefin selectivity. Conversely, iron-containing 69 in the presence of MMAO, displayed moderate activities (up $10.9 \times 10^{4} \mathrm{~g}(\mathrm{PE}) \mathrm{mol}^{-1}(\mathrm{Fe}) \mathrm{h}^{-1}$ ) for ethylene polymerization forming low molecular weight linear polymers (up to $13.0 \mathrm{Kg} \mathrm{mol}^{-1}$ ) containing saturated $n$-propyl and $i$-butyl chain ends. However, it should be emphasized that these complexes bearing $\mathrm{N}, \mathrm{N}, \mathrm{O}$-tridentate ligands generally show lower activity than the corresponding ones bearing $N, N, N$-tridentate ligands [120,121,123]. Elsewhere it should be noted that cycloalkyl-fused $N, N, N$ derivatives have not only proved effective supports for iron and cobalt complexes but have also shown great promise in chromium catalysis in which high activities toward ethylene oligo-/polymerization have been reported [124-126].

\section{$<$ Figure 23 $>$}

In short, the ring size of the cycloalkyl-fused $N, N, N$ ligand has a direct effect on the binding capacity of the chelating support which in-turn influences the activity of the resulting catalyst and oligomer/polymer products.

\section{Mechanistic understanding of $\mathrm{Fe} / \mathrm{Co}$ catalysts in ethylene polymerization}

As a recurring theme from the discussion above, iron and cobalt catalysts can often form mixtures of oligomers and polymers, e.g., linear $\alpha$-olefins accompanied by waxes or polymers from ethylene oligomerization or multimodal or broad molecular weight distributions for ethylene polymerization [43,46,51,119]. Given these observations, researchers around the world have been keen to study the catalytic mechanism of such systems. It is generally accepted that bis(arylimino)pyridine-iron and -cobalt catalysts propagate by a Cossee-Arlman mechanism [127], in which sequential ethylene coordination and migratory insertion of the bound ethylene into a metal alkyl bond occur before some form of chain terminates occurs. However, the formation, the nature, and the reactivity of the intermediates involved still need to be investigated and elucidated. Furthermore, the paramagnetic nature of the catalysts, the multiple oxidation states possible for iron, or the potential non-innocence of the ligands all present further hurdles that hinder their characterization. Nevertheless, some progress has been made and discussed below [43-45]. 


\subsection{The active iron species}

Based on the growing experimental and computational data, the non-innocence of the bis(arylimino)pyridine ligand has been demonstrated [7-15]. Recently, Bryliakov and Talsi used ${ }^{1} \mathrm{H}$ NMR and EPR spectroscopy to identify key active species [128-131]. Through a series of sophisticated NMR experiments, the interaction between the $\left[(\mathbf{L 1}) \mathrm{FeCl}_{2}\right][129]$ and $\left[(\mathbf{L 2}) \mathrm{FeCl}_{2}\right][130,131]$ and various aluminum-based activators such as $\mathrm{MAO}, \mathrm{AlMe}_{3} / \mathrm{B}\left(\mathrm{C}_{6} \mathrm{~F}_{5}\right)_{3}, \mathrm{AlMe}_{3}$ and $\mathrm{Al}(i \mathrm{Bu})_{3}$ was revealed (Scheme 1).

$<$ Scheme 1 $>$

The ion pairs $\quad\left[(\mathbf{L 2}) \mathrm{Fe}(\mu-\mathrm{Cl})(\mu-\mathrm{Me}) \mathrm{AlMe}_{2}\right]^{+}[\mathrm{MeMAO}]^{-}$or $\quad[(\mathbf{L 2}) \mathrm{Fe}$ $\left.(\mu-\mathrm{Cl})(\mu-\mathrm{Me}) \mathrm{AlMe}_{2}\right]^{+}\left[\mathrm{MeB}\left(\mathrm{C}_{6} \mathrm{~F}_{5}\right)_{3}\right]^{-}$were formed when using $\mathrm{MAO}$ or $\mathrm{AlMe} / \mathrm{B}_{3}\left(\mathrm{C}_{6} \mathrm{~F}_{5}\right)_{3}$ as the activators (Scheme 1), while iron(II)-aluminum-bridged neutral species were proposed with an alkylaluminum [129-131]. With respect to the $\left[(\mathbf{L 2}) \mathrm{FeCl}_{2}\right] / \mathrm{MAO}$ system, different types of ion-pair complexes are accessible, depending on the number of equivalents of MAO employed. For an Al/Fe ratio of less than 200:1, [(L2)Fe $\left.(\mu-\mathrm{Cl})(\mu-\mathrm{Me}) \mathrm{AlMe}_{2}\right]^{+}[\mathrm{MeMAO}]^{-}$has been shown, while at ratios of greater than $500: 1$, $\left[(\mathbf{L 2}) \mathrm{Fe}(\mu-\mathrm{Me})_{2} \mathrm{AlMe}_{2}\right]^{+}[\mathrm{MeMAO}]^{-}$has been identified (Scheme 1) [44,45,132-134] However, the species obtained are more complicated than appears on first inspection and indeed the non-innocent behavior of the bis(arylimino)pyridine ligand has been invoked. For example, in the bimetallic intermediate $\left[\left(\mathbf{L 1}^{(-)}\right) \mathrm{Fe}^{(+)}(\mu-\mathrm{X})(\mu-\mathrm{R}) \mathrm{Al}(\mathrm{R})_{2}\right](\mathrm{X}=\mathrm{Cl}$ or $\mathrm{R}$, and $\mathrm{R}=i \mathrm{Bu}$ ), delocalization of an electron over $\mathbf{L 1}$ has been proposed [130-131]. The debate around the oxidation state of the active species for the catalyst is still open and fueled by many spectroscopic [135-137] and theoretical [139-141] studies. The Gibson group has shown that $100 \%$ conversion to a species displaying a +3 oxidation state occurs on treating $\left[(\mathbf{L 1}) \mathrm{FeCl}_{2}\right]$ with MAO by using Mössbauer and EPR spectroscopy [136]. On the other hand, Scott et al. have postulated a complex that is formally zero valent [142]. In a recent DFT study performed by de Bruin and coworkers, they have again concluded that a trivalent oxidation state is most likely, in this case based on an oligomerization catalyst composed of 2 (Fig 2)/MAO system [143]. 
The synthesis and reactivity of potential intermediates [144-149] also could provide support for the observations mentioned above, although the observed species may not be representative of the catalytic system formed under operating conditions. For example, the Chirik group investigated a number of cationic iron(II) species as intermediates in ethylene polymerization $[144,148]$. Complexes $\left[(\mathbf{L 1}) \mathrm{Fe}\left(\mathrm{CH}_{2} \mathrm{SiMe}_{3}\right)(\mathrm{S})\right]^{+}\left[\mathrm{BPh}_{4}\right]^{-}(\mathrm{S}=$ $\mathrm{Et}_{2} \mathrm{O}$ or THF) and $\left[(\mathbf{L 1}) \mathrm{Fe}\left(\mathrm{CH}_{2} \mathrm{SiMe}_{2} \mathrm{CH}_{2} \mathrm{SiMe}_{3}\right)(\mathrm{S})\right]^{+}\left[\mathrm{MeB}\left(\mathrm{C}_{6} \mathrm{~F}_{5}\right)_{3}\right]^{-}$(Figure 24) were isolated and characterized by single crystal X-ray diffraction. These model bis(arylimino)pyridine-iron(II)-alkyl cations were obtained by dialkylation of $\left[(\mathbf{L 1}) \mathrm{FeCl}_{2}\right]$ followed by subsequent alkyl abstraction by a boron-based compound (Figure 24). When in contact with ethylene, these isolated single-component cationic systems exhibited moderate catalytic activities (up to $9.42 \times 10^{5} \mathrm{~g} \mathrm{PE} \mathrm{mol}^{-1}(\mathrm{Fe}) \mathrm{h}^{-1} \mathrm{bar}^{-1}$ ) affording highly linear polymers with high $M_{\mathrm{w}}$ (up to $3.17 \times 10^{5} \mathrm{~g} \mathrm{~mol}^{-1}$ ) and relatively narrow molecular weight distributions $(1.6 \sim 2.5)$ [147]. Through the isolation of such cationic (as well as neutral and anionic) bis(arylimino)pyridine-iron alkyl complexes (Figure 24), the same group also later showed the redox non-innocence of the bis(arylimino)pyridine chelate [149].

\section{$<$ Figure 24 $>$}

Recently, Cámpora et al. utilized single crystal X-ray diffraction and in situ ${ }^{1} \mathrm{H}$ NMR spectroscopy in the characterization of intermediates formed by the reduction of $\left[(\mathbf{L 1}) \mathrm{Fe}\left(\mathrm{CH}_{2} \mathrm{SiMe}_{3}\right)_{2}\right]$ by $\mathrm{AlMe}_{3}[150]$. A neutral [(L1)Fe(II)Me] intermediate (Figure 24) was observed as the final product of the reaction in which a single electron reduction of the chelating ligand was suspected. When treated with ethylene, the species in the polymerization reaction were monitored by ${ }^{1} \mathrm{H}$ NMR spectroscopy [151]. Using NMR spectroscopy, Gibson and Britovsek observed that the process of binding of the ethylene monomer to the mono-methyl complex and the growth of the alkyl chain on the iron center via ethylene insertion [152]. These results present direct evidence of a coordination-insertion mechanism when ethylene is oligomerized by such propagating species, in line with the H/D scrambling and mass spectrometric experiments, and hence supporting a Cossee-Arlman mechanism [127,152]. However, in comparison with their cationic analogues, the considerably lower activities and polymer molecular weights 
question their involvement in the catalytic multi-component ethylene polymerization process. Recently, in a combined experimental and theoretical study, the de Bruin group described the activation process of a single-site ethylene oligomerization catalyst with a novel and well-defined phenoxyaluminum, [PhOAlMe$]_{2}$ [153]. When compared to either $\mathrm{AlMe}_{3}$ or $\mathrm{MAO}$, the resulting catalyst is less active than with MAO. Nevertheless, this well-defined species presents interesting features and a feasible path for further characterization study and catalytic optimization [153].

\subsection{The active cobalt species}

As with iron, the mode activation of bis(arylimino)pyridine-cobalt halide complexes with MAO has been the subject of a number of investigations which have shown some interesting findings. Using $d_{6}$-labeled bis(arylimino)pyridine (L1) as an example, ${ }^{2} \mathrm{H}$ NMR spectroscopy has been used to monitor the activation of $\left[\mathbf{L 1}_{d 6} \mathrm{CoCl}_{2}\right]$ with MAO (Scheme 2) and subsequent interaction with ethylene [154,155].

\section{$<$ Scheme 2 $>$}

With regard to $\left[\mathbf{L 1}_{d \sigma} \mathrm{CoCl}_{2}\right] / \mathrm{MAO}$, reduction of the cobalt(II) complex to cobalt(I) halide is followed by conversion to a cobalt(I) methyl species before conversion to a cobalt(I) cationic species, has been demonstrated $[44,45,154,155]$. When the cationic species was treated with ethylene the adduct $\left[\mathbf{L} \mathbf{1}_{d 6} \mathrm{Co}\left(\eta^{2}-\mathrm{C}_{2} \mathrm{H}_{4}\right)\right][\mathrm{MeMAO}]$ was generated which represents a likely precursor to the active species (Scheme 2). By running the polymerization with $\left[\mathbf{L}_{d 6} \mathrm{CoCl}_{2}\right]$ and per-deuterated $\mathrm{MAO}$, polymers could be obtained with $\mathrm{CD}_{3}$ end-groups, consistent with an abstracted methide group being re-incorporated into the polymer. Based on this finding it has been proposed that a methide group from $[\mathrm{MeMAO}]^{-}$can attack the cobalt center with concomitant electrophilic attack by the Lewis acid on the bound ethylene to afford the zwitterionic cobalt dialkyl active species [155]. Chain growth can then place via either of the cobalt-carbon bonds. Notably, the isolated bis(arylimino)pyridine-cobalt(I)-methyl complex does not insert olefins but on treatment with $\mathrm{MAO}$ or a borate activator, is active for ethylene polymerization $[149,154-159]$. 


\subsection{Propagation and chain transfer pathways/theoretical studies}

As highlighted above the mechanism of propagation for both iron and cobalt catalysts is considered to follow a Cossee-type mechanism [127], in which ethylene coordination and migratory insertion of the bound ethylene into a metal alkyl bond sequentially occur before chain transfer terminates the reaction. In general, four different chain transfer pathways can be identified [43-46,56]. In the first pathway, the process of chain transfer to the aluminum terminates the reaction and forms polyethylenes with saturated alkyl-containing chain ends $[44,45,56]$. This process has also been observed for Ziegler-Natta systems [160], group 4 metallocenes [161-163] and lanthanocenes [164] and is dependent upon the alkyl aluminum concentration. The vinyl-polyethylenes can be obtained by three further distinct chain-transfer pathways (Scheme 3). Two make use of kinetically distinct $\beta-\mathrm{H}$ transfer to metal processes (Scheme 3, distinguished in blue or red) and a third involves $\beta-\mathrm{H}$ transfer to monomer (Scheme 3). Commonly, $\beta-\mathrm{H}$ transfer to metal (via blue route, Scheme 3) is the key chain-transfer process and often takes place with late transition metal catalysts. This $\beta-\mathrm{H}$ elimination reaction is independent of monomer concentration, provided that the subsequent step, the associative displacement of the polymer chain by monomer, is fast. Otherwise, this chain-transfer process becomes a $\beta$-H transfer to metal (red route, Scheme 3), which is kinetically indistinguishable from $\beta-\mathrm{H}$ transfer to monomer (Scheme 3). Overall, for $\beta$-H-transfer reactions to the metal or the monomer, one unsaturated chain end per polymer chain (vinyl end-groups) will be the outcome, whereas chain transfer to aluminum results in fully saturated polymer chains $[44,45,56]$.

\section{$<$ Scheme 3 $>$}

\section{Conclusions and outlook}

The discovery of highly active iron and cobalt catalysts some twenty years ago has proved a landmark in the development of late transition metal olefin polymerization catalysts. In this account, we have shown there are still important advances to be made in this relatively established field. In particular, we have documented the outcomes of our program to introduce robust modifications to the parent bis(arylimino)pyridine 
pincer ligand and its derivatives through the fusion of carbocyclic units. These structural variations have provided a means of modulating the activity of the metal catalyst during the ethylene oligo-/polymerization process. While some modifications have resulted in decreased catalytic activity, the development of cycloalkyl-fused bis(arylimino)pyridine-iron and -cobalt catalysts that show exceptionally high activities and good temperature stability highlights the true potential of this approach. Importantly, the size of the fused ring can impact on the oligomer/polymer distribution with mixtures apparent with six-membered rings, while other ring sizes display a preference for either oligomer or polymer. Furthermore, it can also affect the chain end-type with the seven-membered-fused derivatives of iron and cobalt displaying an inclination for vinyl chain-ends. Nevertheless, strictly linear microstructures are a feature of all the oligomers or polymers developed using these iron and cobalt catalysts. Perhaps most significantly, carbocyclic fused $N, N, N$-iron complexes have finally shown genuine industrial promise with an imino-phenanthroline-iron complex being successfully employed to make $\alpha$-olefins on in a 500 ton pilot plant managed by Sinopec in China. The relatively low cost of this system based on an earth-abundant base metal, coupled with its high efficiency, suggests that such catalysts are likely to attract future industrial interest. Overall, we feel the work described herein should help fuel new academic endeavors directed towards targeting late-transition metal pre-catalysts, which in-turn will deliver new oligomers and/or polymer products for potential commercial end-uses.

\section{Acknowledgements}

This work is supported by the National Natural Science Foundation of China (21374123, 21476060, and U1362204). G.A.S. thanks the Chinese Academy of Sciences for a Visiting Scientist Fellowship.

\section{GLOSSARY}

$\begin{array}{ll}\text { DFT } & \text { Density Functional Theory } \\ \text { DSC } & \text { Differential Scanning Calorimetry } \\ \text { g PE } \text { mol }^{-1}(M) h^{-1} & \text { Grams of polyethylene per mole of metal }\end{array}$


catalyst per hour

GPC

$\mathrm{K}$ value

MAO

MMAO

MWD

$M_{\mathrm{w}}$

$M_{\mathrm{n}}$

NMR

PDI

PE

py
Gel Permeation Chromatography

The probability of propagation

Methylaluminoxane

Modified methylaluminoxane

Molecular weight distribution

Weight-average molecular weight

Number-average molecular weight

Nuclear magnetic resonance

Polydispersity index

Polyethylene

Pyridine

\section{References}

[1] T. Zell and D. Milstein, Acc. Chem. Res. 48 (2015) 1979-1994.

[2] B. L. Small, Acc. Chem. Res. 48 (2015) 2599-2611.

[3] R. H. Morris, Acc. Chem. Res. 48 (2015) 1494-1502.

[4] S. Chakraborty, P. Bhattacharya, H. Dai and H. Guan, Acc. Chem. Res. 48 (2015) 1995-2003.

[5] P. Gandeepan and C. H. Cheng, Acc. Chem. Res. 48 (2015) 194-1206.

[6] I. Bauer and H. J. Knolker, Chem. Rev. 115 (2015) 3170-3387.

[7] P. J. Chirik, Acc. Chem. Res. 48 (2015) 1687-1695.

[8] B. Burcher, P. -A. R. Breuil, L. Magna, and H. Olivier-Bourbigou, Top Organomet Chem. 50 (2015) 217-258.

[9] S. A. Ryken, L. L. Schafer, Acc. Chem. Res. 48 (2015) 2576-2586.

[10]M. Sturzel, S. Mihan, R. Mulhaupt, Chem. Rev. 116 (2016) 1398-1433.

[11] A.M. Zima, O.Y. Lyakin, R.V. Ottenbacher, K. P. Bryliakov, E. P. Talsi, ACS Catal. 7 (2016) 60-69.

[12] K. P. Bryliakov, E. P. Talsi, Coord. Chem. Rev. 256 (2012) 2994-3007.

[13] N. Guo, M.-Y. Hu, Y. Feng, S.-F. Zhu, Org. Chem. Front. 2 (2015) 692-696.

[14]N. M. Rezayee, D. C. Samblanet, M. S. Sanford, ACS Catal. 6 (2016) 6377-6383.

[15] S. Chakraborty, H. Dai, P. Bhattacharya, N. T. Fairweather, M. S. Gibson, J. A. Krause, H. Guan, J. Am. Chem. Soc. 136 (2014) 7869-7872.

[16] S. Werkmeister, K. Junge, B. Wendt, E. Alberico, H. Jiao, W. Baumann, H. Junge, F. Gallou, M. Beller, Angew. Chem. Int. Ed. 53 (2014) 8722-8726

[17] T. Zell, Y. Ben-David, D. Milstein, Angew. Chem. Int. Ed. 53 (2014) 4685-4689.

[18] C. Bornschein, S. Werkmeister, B. Wendt, H. Jiao, E. Alberico, W. Baumann, H. Junge, K. Junge, M. Beller, Nat. Comm. 5 (2014) 4111.

[19] S. Lange, S. Elangovan, C. Cordes, A. Spannenberg, H. Jiao, H. Junge, S. Bachmann, M. Scalone, C. Topf, K. Junge, M. Beller, Catal. Sci. Technol. 6 (2016) 4768-4772. 
[20]F. Schneck, M. Assmann, M. Balmer, K. Harms, R. Langer, Organometallics 35 (2016) 1931-1943.

[21] B. Butschke, M. Feller, Y. Diskin-Posner, D. Milstein, Catal. Sci. Technol. 6 (2016) 4428-4437.

[22] J. Yuwen, S. Chakraborty, W. W. Brennessel, W. D. Jones, ACS Catal. 7 (2017) 3735-3740.

[23] D. Srimani, A. Mukherjee, A.F. Goldberg, G. Leitus, Y. Diskin-Posner, L. J. Shimon, Y. Ben-David, D. Milstein, Angew. Chem. Int. Ed. 54 (2015) 12357-12360.

[24] S. Fu, N. Y. Chen, X. Liu, Z. Shao, S. P. Luo, Q. Liu, J. Am. Chem. Soc. 138 (2016) 8588-8594.

[25] T. P. Lin, J. C. Peters, J. Am. Chem. Soc. 136 (2014) 13672-13683

[26] T. J. Korstanje, J. I. Vlugt, C. J. Elsevier, B. Bruin, Science 350 (2015) 298-302.

[27] H. Zhang, Z. Lu, ACS Catal. 6 (2016) 6596-6600.

[28] A. Mukherjee, D. Srimani, S. Chakraborty, Y. Ben-David, D. Milstein, J. Am. Chem. Soc. 137 (2015) 8888-8891.

[29] M. Sturzel, S. Mihan, R. Mulhaupt, Chem. Rev. 116 (2016) 1398-1433.

[30] E. Alberico, P. Sponholz, C. Cordes, M. Nielsen, H. J. Drexler, W. Baumann, H. Junge, M. Beller, Angew. Chem. Int. Ed. 52 (2013) 14162-14166.

[31] I. Mellone, N. Gorgas, F. Bertini, M. Peruzzini, K. Kirchner, L. S Gonsalvi, Organometallics 35 (2016) 3344-3349.

[32]E. A. Bielinski, M. Förster, Y. Zhang, W. H. Bernskoetter, N. Hazari, M. C. B. Holthausen, ACS Catal. 5 (2015) 2404-2415.

[33] S. Chakraborty, P. O. Lagaditis, M. Förster, E. A. Bielinski, N. Hazari, M. C. Holthausen, W. D. Jones, S. Schneider, ACS Catal. 4 (2014) 3994-4003.

[34] G. Zhang, and S. K. Hanson, Org. Lett. 15 (2013) 650-653.

[35]E. Balaraman, A. Nandakumar, G. Jaiswal, M. K. Sahoo, Catal. Sci. Technol. 7 (2017) 3177-3195.

[36]Y. Y. Li, S. L. Yu, W. Y. Shen and J. X. Gao, Acc. Chem. Res. 48 (2015) 2587-2598.

[37]P. Daw, S. Chakraborty, A. J. Garg, Y. Ben-David and D. Milstein, Angew. Chem. Int. Ed. 55 (2016) 14373-14377.

[38]Z. Yin, H. Zeng, J. Wu, S. Zheng, G. Zhang, ACS Catal. 6 (2016) 6546-6550.

[39]N. Deibl, R. Kempe, J. Am. Chem. Soc. 138 (2016) 10786-10789.

[40] D. Takeuchi, K. Osakada, Polymer 49 (2008) 4911-4924.

[41]D. Takeuchi, R. Matsuura, Y. Fukuda, K. Osakada, Dalton Trans. (2009) 8955-8962

[42] D. Gong, X. Zhang, K.-W. Huang, Dalton Trans. 45 (2016) 19399-19407.

[43]Z. Flisak, W.-H. Sun, ACS Catal. 5 (2015) 4713-4724.

[44] V. C. Gibson, G. A. Solan, in Catalysis without Precious Metals (Ed. M. Bullock), Wiley-VCH, Weinheim, (2010) 111-141.

[45] V. C. Gibson, G. A. Solan, Top. Organomet. Chem. 26 (2009) 107-158.

[46] W. Zhang, W.-H. Sun, C. Redshaw, Dalton Trans. 42 (2013) 8988-8997.

[47] S. D. Ittel, L. K. Johnson, M. Brookhart, Chem. Rev. 100 (2000) 1169-1203

[48] C. Bianchini, G. Giambastiani, I. G. Rios, G. Mantovani, A. Meli, A. M. Segarra, Coord. Chem. Rev. , 250 (2006) 1391-1418.

[49] C. Bianchini, G. Giambastiani, L. Luconi, A. Meli, Coord. Chem. Rev. 254 (2010) 431-455. 
[50] V. C. Gibson, C. Redshaw, G. A. Solan, Chem. Rev. 107 (2007) 1745-1776.

[51] J. Ma, C. Feng, S. Wang, K.-Q. Zhao, W.-H. Sun, C. Redshaw and G. A. Solan. Inorg. Chem. Front. 1 (2014) 14-34.

[52] B. L. Small, M. Brookhart, A. M. A. Bennett, J. Am. Chem. Soc. 120 (1998), 4049-4050.

[53] G. J. P. Britovsek, V. C. Gibson, B. S. Kimberley, P. J. Maddox, S. J. McTavish, G. A. Solan, A. J. P. White, D. J. Williams, Chem. Commun. (1998) 849-850.

[54] G. J. P. Britovsek, M. Bruce, V. C. Gibson, B. S. Kimberley, P. J. Maddox, S. Mastroianni, S. J. McTavish, C. Redshaw, G. A. Solan, S. Stromberg, A. J. P. White, D. J. Williams, J. Am. Chem. Soc. 121 (1999) 8728-8740

[55]B. L. Small, M. Brookhart, J. Am. Chem. Soc. 120 (1998), 7143-7144.

[56] G. J. P. Britovsek, S. Mastroianni, G. A. Solan, S. P. D. Baugh, C. Redshaw, V. C. Gibson, A. J. P. White, D. J. Williams, M. R. Elsegood, J. Chem. Eur. J. 6 (2000) 2221-2231.

[57] Y. Chen, C. Qian, J. Sun, Organometallics 22 (2003) 1231-1236.

[58] Y. Chen, R. Chen, C. Qian, X. Dong and J. Sun, Organometallics 22 (2003) 4312-4321.

[59] C. Görl, H. G. Alt, J. Organomet. Chem. 692 (2007) 4580-4592.

[60] C. Görl, H. G. Alt, J. Mol. Catal. A: Chem. 273 (2007) 118-132.

[61]F. Kaul, K. Puchta, G. Frey, E. Herdtweck, W. Herrmann, Organometallics 26 (2007) 988-999.

[62] A. S. Ionkin, W. J. Marshall, D. J. Adelman, B. B. Fones, B. M. Fish, M. F. Schiffhauer, P. D. Soper, R. L. Waterland, R. E. Spence, T. Xie, J. Polym. Sci., Part A: Polym. Chem. 46 (2008) 585-611.

[63] A. S. Ionkin, W. J. Marshall, A. J. Adelman, B. B. Fones, B. M. Fish, M. F. Schiffhauer, Organometallics 27 (2008) 1902-1911.

[64] G. Wallenhorst, G. Kehr, H. Luftmann, R. Fröhlich, G. Erker, Organometallics 27 (2008) 6547-6556.

[65] J. Cámpora, A. M. Naz, P. Palma, A. Rodríguez-Delgado, E. Álvarez, I. Tritto, L. I. Boggioni, Eur. J. Inorg. Chem. (2008) 1871-1879.

[66]Z. Long, B. Wu, P. Y. Yang, G. Li, Y. Liu, X.-J. Yang, J. Organomet. Chem. 694 (2009) 3793-3799.

[67] G. Xie, T. Li, A. Zhang. Inorg, Chem. Commun. 13 (2010) 1199-1202.

[68] T. Zhang, W.-H. Sun, T. Li, X. Yang, J. Mol. Catal. A: Chem. 218 (2004) 119-124.

[69] L.-H. Guo, H. -Y. Gao, L. Zhang, F. Zhu, Q. Wu, Organometallics 29 (2010) 2118-2125.

[70] J. Yu, H. Liu, W. Zhang, X. Hao, W.-H. Sun, Chem. Commun.47 (2011) 3257-3259.

[71] J. Yu, W. Huang, L. Wang, C. Redshaw, W. H. Sun, Dalton Trans. 40 (2011) 10209-10214.

[72]X. Cao, F. He, W. Zhao, Z. Cai, X. Hao, T. Shiono, C. Redshaw, W.-H. Sun, Polymer 53 (2012), 1870-1880.

[73] N. V. Semikolenova, W.-H. Sun, I. E. Soshnikov, M. A. Matsko, O. V. Kolesova, V. A. Zakharov, K. P. Bryliakov, ACS Catal.7 (2017) 2868-2877.

[74]F. He, W. Zhao, X.-P. Cao, T. Liang, C. Redshaw, W.-H. Sun, J. Organomet. Chem. 713 (2012) 209-216.

[75] W. Zhao, J. Yu, S. Song, W. Yang, H. Liu, X. Hao, C. Redshaw, W.-H. Sun, Polymer. 53 (2012) $130-137$.

[76] J. Lai, W. Zhao, W. Yang, C. Redshaw, T. Liang, Y. Liu, W.-H. Sun, Polym. Chem. 3 (2012) 787-793. 
[77] S. Wang, B. Li, T. Liang, C. Redshaw, Li, Y.; W. H. Sun, Dalton Trans. 42 (2013) 9188-9197.

[78] W.-H. Sun, W. Zhao, J. Yu, W. Zhang, X. Hao, C. Redshaw, Macromol. Chem. Phys. 213 (2012), 1266-1273.

[79] S. Wang, W. Zhao, X. Hao, B. Li, C. Redshaw, Y. Li, W.-H. Sun, J. Organomet. Chem. 731 (2013) 78-84.

[80] W. Zhang, S. Wang, S. Du, C.-Y. Guo, X. Hao, W.-H. Sun, Macromol. Chem. Phys. 215 (2014) 1797-1809.

[81] W. Zhao, E. Yue, X. Wang, W. Yang, Y. Chen, X. Hao, X. Cao, W.-H. Sun, J. Polym. Sci., Part A: Polym. Chem. 55 (2017) 988-996.

[82] L. Wang, W. -H. Sun, L. Han, H. Yang, Y. Hu, X, Jin, J. Organomet. Chem. 658 (2002) 62-70.

[83] G. J. P. Britovsek, S. P. D. Baugh, O. Hoarau, V. C. Gibson, D. F. Wass, A. J. P. White, D. J. Williams, Inorg. Chim. Acta. 345 (2003) 279-291.

[84] W.-H. Sun, S. Jie, S. Zhang, W. Zhang, Y. Song, H. Ma, Organometallics 25 (2006) 666-677.

[85] S. Jie, S. Zhang, W. -H. Sun, X. Kuang, T. Liu, J. Guo, J. Mol. Catal. A: Chem. 269 (2007) 85-96.

[86] M. Zhang, W. Zhang, T. Xiao, J. -F. Xiang, X. Hao, W.-H. Sun, J. Mol. Catal. A: Chem. 320 (2010) 92-96.

[87] S. Jie, S. Zhang, K. Wedeking, W. Zhang, H. Ma, X. Lu, Y. Deng, W. -H. Sun, C. R. Chim. 9 (2006) 1500-1509.

[88] J. D. A. Pelletier, Y. D. M. Champouret, J. Cadarso, L. Clowes, M. Gañete, K. Singh, V. Thanarajasingham, G. A. Solan, J. Organomet. Chem. 691 (2006) 4114-4123.

[89] S. Jie, S. Zhang, W.-H. Sun, Eur. J. Inorg. Chem. (2007) 5584-5598.

[90] M. Zhang, P. Hao, W. Zuo, S. Jie, W.-H. Sun, J. Organomet. Chem. 693 (2008) 483-491.

[91] M. Zhang, R. Gao, X. Hao, W.-H. Sun, J. Organomet. Chem. 693 (2008) 3867-3877.

[92] W. -H. Sun, P. Hao, G. Li, S. Zhang, W. Wang, J. Yi, M. Asma, N. Tang, J. Organomet. Chem. 692 (2007) 4506-4518.

[93] L. Xiao, R. Gao, M. Zhang, Y. Li, X. Cao, W.-H. Sun, Organometallics 28 (2009) 2225-2233.

[94] W.-H. Sun, P. Hao, S. Zhang, Q. Shi, W. Zuo, X. Tang, X. Lu, Organometallics 26 (2007) 2720-2734.

[95] Y. Chen, P. Hao, W. Zuo, K. Gao, W.-H. Sun, J Organomet. Chem. 693 (2008) 1829-1840.

[96] L. Zhang, X. Hou, J. Yu, X. Chen, X. Hao, W.-H. Sun, Inorg. Chim. Acta. 379 (2011) 70-75.

[97] R. Gao, Y. Li, F. Wang, W.-H. Sun, Eur. J. Inorg. Chem. 309 (2009) 166-171.

[98] S. Song, R. Gao, M. Zhang, Y. Li, F. Wang, W.-H. Sun, Inorg. Chim. Acta. 376 (2011) 373-380.

[99] G. M. Lenges, U. S. Pat. (2002) 0061987 A1

[100] Y. Nakayama, Y. Baba, H. Yasuda, K. Kawakita, N. Ueyama, Macromolecules 36 (2003) 7953-7961.

[101] D. Zabel, A. Schubert, G. Wolmershäuser, R. L. Jones Jr, W. R. Thiel, Eur. J. Inorg. Chem. (2008) 3648-3654.

[102] A. R. Karama, E. L. Catarĺa, F. López-Linaresa, G. Agrifoglioa, C. L. Albanoa, A. Dĺaz-Barriosa, T. E. Lehmanna, S. V. Pekerara, L. A. Albornoza, R. Atencioa, T. Gonzáleza, H. B. Ortegab, P. Joskowics, Appl. Catal. A: Gen. 280 (2005) 165-173. 
[103] H. S. Aboo, S. J. J. Titinchi, Catal. Lett. 139 (2010) 90-96.

[104] K. Tenza, M. J. Hanton, A. M. Z. Slawin, Organometallics 28 (2009) 4852-4867.

[105] K. Nomura, S. Warit, Y. Imanishi, Bull. Chem. Soc. Jpn. 73 (2000) 599-605.

[106] Z. Wang, Q. Liu, G. A. Solan, W.-H. Sun, Coord. Chem. Rev. 350 (2017) 68-83.

[107] S. Wang, W.-H. Sun, C. Redshaw, J. Organomet. Chem. 751 (2014) 717-741.

[108] R. Gao, W.-H. Sun, C. Redshaw, Catal. Sci. Technol. 3 (2013) 1172-1179.

[109] L. Zhang, X. Hao, W.-H. Sun, C. Redshaw, ACS Catal. 1 (2011), 1213-1220.

[110] I. E. Soshnikov, N. V. Semikolenova, K. P. Bryliakov, V. A. Zakharov, W.-H. Sun, E. P. Talsi, Organometallics 34 (2015) 3222-3227.

[111] W. Zhang, W. Chai, W.-H. Sun, X. Hu, C. Redshaw, X. Hao, Organometallics 31 (2012) 5039-5048.

[112] W.-H. Sun, S. Kong, W. Chai, T. Shiono, C. Redshaw, X. Hu, C. Guo, X. Hao, Appl. Catal. A: Gen. 447-448 (2012), 67-73.

[113] J. Ba, S. Du, E. Yue, X. Hu, Z. Flisak, W.-H. Sun, RSC Adv. 5 (2015) 32720-32729.

[114] F. Huang, Q. Xing, T. Liang, Z. Flisak, B. Ye, X. Hu, W. Yang, W.-H. Sun, Dalton Trans. 43 (2014) 16818-16829.

[115] Y. Zhang, H. Suo, F. Huang, T. Liang, X. Hu, W.-H. Sun, J. Polym. Sci. Part A: Polym.Chem. 55 (2017) 830-842.

[116] F. Huang, W. Zhang, E. Yue, T. Liang, X. Hu, W.-H. Sun, Dalton Trans. 45 (2016) 657-666.

[117] F. Huang, W. Zhang, Y. Sun, X. Hu, G. A. Solan, W.-H. Sun, New J. Chem. 40 (2016) 8012-8023.

[118] H. Zhou, S. Wang, H. Huang, Z. Li, C. M. Plummer, S. Wang, W.-H. Sun, Y. Chen. Macromolecules 50 (2017) 3510-3515

[119] V. K. Appukuttan, Y. Liu, B. C. Son, C.-S. Ha, H. Suh, I. Kim, Organometallics 30 (2011) 2285-2294.

[120] S. Du, X. Wang, W. Zhang, Z. Flisak, Y. Sun, W.-H. Sun, Polym. Chem. 7 (2016) 4188-4197.

[121] S. Du, W. Zhang, E. Yue, F. Huang, T. Liang, W.-H. Sun, Eur. J. Inorg. Chem. (2016) 1748-1755.

[122] Z. Wang, G. A. Solan, Q. Mahmood, Q. Liu, Y. Ma, X. Hao, W.-H. Sun, Organometallics 37 (2018) 380-389.

[123] C. Bariashir, Z. Wang, S. Du, G. A. Solan, C. Huang, T. Liang, W.-H. Sun, J. Polym. Sci., Part A: Polym. Chem. 55 (2017) 3980-3989

[124] C. Huang, S. Du, G. A. Solan, Y. Sun, W.-H. Sun, Dalton Trans. 46 (2017) 6948-6957;

[125] C. Huang, Y. Zhang, G. A. Solan, Y. Ma, X. Hu, Y. Sun, W.-H. Sun, Eur. J. Inorg. Chem. (2017) 4158-4166;

[126] Y. Zhang, C. Huang, X. Hao, X. Hu, and W.-H. Sun, RSC Adv. 6 (2016) 91401-91408.

[127] P. Cossee, J. Catal. 3 (1964) 80-88.

[128] E. Talsi, K. Bryliakov. Applications of EPR and NMR Spectroscopy in Homogeneous Catalysis. (2017) CRC Press. Taylor \& Francis Group. 
[129] K. P. Bryliakov, E. P. Talsi, N. V. Semikolenova, V. A. Zakharov, Organometallics. 28 (2009) 3225-3232.

[130] E. P. Talsi, D. E. Babushkin, N. V. Semikolenova, V. N. Zudin, V. N. Panchenko, V. A. Zakharov, Macromol. Chem. Phys. 202 (2001) 2046-2051.

[131] K. P. Bryliakov, N. V. Semikolenova, V. A. Zakharov, E. P. Talsi, Organometallics. 23 (2004) 5375-5378.

[132] Q. Wang, H. Yang, Z. Fan, Macromol. Rapid Commun. 23(2002) 639-642.

[133] K. Radhakrishnan, H. Cramail, A. Deffeux, P. Francois, A. Momtaz, Macromol. Rapid Commun. 24 (2003) 251-254.

[134] A. A. Barabanov, G. D. Bukatov, V. A. Zakharov, N. V. Semikolenova, L. G. Echevskaja, M. A Matsko, Macromol. Chem. Phys. 206 (2005) 2292-2298.

[135] K. P. Bryliakov, N. V. Semikolenova, V. N. Zudin, V. A. Zakharov, E. P. Talsi, Catal. Commun. 5 (2004) 45-48.

[136] G. J. P. Britovsek, G. K. B, Clentsmith, V. C. Gibson, D. M. L. Goodgame, S. J. McTavish, Q. A. Pankhurst, Catal. Commun. 3 (2002) 207-211.

[137] P. M. Castro, P. Lahtinen, K. Axenov, J. Viidanoja, T. Kotiaho, M. Leskelä, T. Repo, Organometallics 24 (2005) 3664-3670.

[138] V.c.L. Cruz, J. Ramos, J. Martínez-Salazar, S. Gutiérrez-Oliva, A. Toro-Labbé, Organometallics 28 (2009) 5889-5895.

[139] L. Deng, P. Margl, T. Ziegler, J. Am. Chem. Soc. 121 (1999) 6479-6487.

[140] D. V. Khoroshun, D. G. Musaev, T. Vreven, K. Morokuma, Organometallics 20 (2001) 2007-2026.

[141] E. A. H. Griffiths, G. J. P. Britovsek, V. C. Gibson, I. R. Gould, Chem. Commun. (1999) 1333-1334.

[142] J. Scott, S. Gambarotta, I. Korobkov, P. H. M. Budzelaar, Organometallics 24 (2005) 6298-6300.

[143] R. Raucoules, T. de Bruin, P. Raybaud, C. Adamo, Organometallics 27(2008) 3368-3377.

[144] I. Fernández, R. J Trovitch, E, P, Lobkovsky, J. Chirik, Organometallics 27 (2008) 109-118.

[145] J. Scott, S. Gambarotta, I. Korobkov, P. H. M Budzelaar, Organometallics 24 (2005) 6298-6300.

[146] J Cámpora, A. M. Naz, P. Palma, E. Álvarez, M. L. Reyes, Organometallics 24 (2005) 4878-4881.

[147] J. Scott, S. Gambarotta, I. Korobkov, P. H. M. Budzelaar, J. Am. Chem. Soc. 127 (2005) 13019-13029.

[148] M. W. Bouwkamp, E. Lobkovsky, P. J. Chirik, J. Am. Chem. Soc. 127 (2005) 9660-9661.

[149] A. M. Tondreau, C. Milsmann, A. D. Patrick, H. M. Hoyt, E. Loblovsky, K. Wieghardt, P. J. Chirik, J. Am. Chem. Soc. 132 (2010) 15046-15059.

[150] M. A. Cartes, A. Rodríguez-Delgado, P. Palma, E. Alvarez, J. Cámpora, Organometallics 33 (2014) 1834-1839.

[151] M. A. Cartes, A. Rodríguez-Delgado, P. Palma, L. J. Sánchez, J. Cámpora, Catal. Sci. Technol. 
4 (2014) 2504-2507.

[152] A. K. Tomov, V. C. Gibson, G. J. P. Britovsek, R. J. Long, M. Meurs, D. J. Jones, K. P. Tellmann, J. J. Chirinos, Organometallics 28 (2009) 7033-7040.

[153] Z. Boudene, A. Boudier, P. A. R. Breuil, O. Olivier-Bourbigou, P. Raybaud, H. Toulhoat, T. de Bruin, J. Catal. 317 (2014)153-157.

[154] T. M. Kooistra, Q. Knijnenburg, J. M. M. Smits, A. D. Horton, P. H. M. Budzelaar, A. W. Gal, Angew. Chem. Int. Ed. 40 (2001) 4719-4722.

[155] M. J. Humphries, K. P. Tellmann, V. C. Gibson, A. J. P. White, D. J. Williams, Organometallics 24 (2005) 2039-2050.

[156] I. E. Soshnikov, N. V. Semikolenova, A. N. Bushmelev, K. P. Bryliakov, O. Y. Lyakin, C. Redshaw, V. A. Zakharov, E. P. Talsi, Organometallics 28 (2009) 6003-6013.

[157] M. J. Humphries, K. P. Tellmann, V. C. Gibson, A. J. P White, D. J. Williams. Organometallics Organometallics 23 (2004) 5503-5513.

[158] V. C. Gibson, M. J. Humphries, K. P. Tellmann, D. F. Wass, A. J. P. White, D. J. Williams, Chem. Commun. (2001) 2252-2253.

[159] W. Steffen, T. Blömker, N. Kleigrewe, G. Kehr, R. Fröhlich, G. Erker, Chem. Commun. (2004) 1188-1189.

[160] M. M. V. Marques, C. P. Nunes, P. J. T. Tait, A. R. Dias. J. Polym. Sci., Part A: Polym. Chem. 31 (1993) 219-225.

[161] V. Busico, R. Cipullo, Macromolecules 27(1994) 7538-7543.

[162] M. Bochmann, S. J. Lancaster, Angew. Chem. Int. Ed. Engl. 33 (1994) 1634-1637.

[163] A. Zambelli, P. Longo, A Grassi, Macromolecules 22 (1989) 2186-2189.

[164] F. Pelletier, A. Mortreux, X. Olonde, K. Bujadoux, Angew. Chem. Int. Ed. Engl. 35 (1996) $1854-1856$ 


\section{Captions for Schemes, Tables and Figures}

Scheme 1 Reactivity of $\left[(\mathbf{L} 1) \mathrm{FeCl}_{2}\right]$ and $\left[(\mathbf{L} 2) \mathrm{FeCl}_{2}\right]$ towards $\mathrm{MAO}, \mathrm{AlMe}_{3}$ and $\mathrm{AlMe}_{3} / \mathrm{B}\left(\mathrm{C}_{6} \mathrm{~F}_{5}\right)_{3}[44,45$, 129-131].

Scheme 2 Proposed mechanism for the activation $\left[\mathbf{L 1}_{d \sigma} \mathrm{CoCl}_{2}\right]$ with $\mathrm{MAO}$ and interaction with ethylene $[44,45,153,155]$

Scheme 3 Two potential mechanisms for the formation of vinyl-polyethylenes $[44,45,56]$

Table 1 Catalytic performance of para-halide- and alkyl-substituted bis(arylimino)pyridine-iron pre-catalysts [59]

Table 2 Variation in the polyethylene properties as a function of the iron and cobalt pre-catalyst structure and temperature.

Table 3 Catalytic performance of 2-imino-1,10-phenanthroline-iron complexes.

Table 4 Catalytic performance using 2-(2-benzimidazolyl)-6-(1-(arylimino)-ethyl)pyridine -iron pre-catalysts.

Table 5 Variation in polyethylene properties as a function of the iron pre-catalyst structure, temperature and activity; MAO activation

Table 6 Variation in polyethylene properties as a function of the cobalt pre-catalyst structure, temperature and activity; MAO activation.

Figure 1 Evolution of the bis(arylimino)pyridine ligand frame (A) through incorporation of carbocyclic-fused units to give $\mathbf{B}$ and $\mathbf{C}[43,46,51-54]$

Figure 2 First generation bis(arylimino)pyridine-iron(II) and -cobalt(II) pre-catalysts 1 and 2 [52-56]

Figure 3 Halide-substituted bis(arylimino)pyridine-iron and -cobalt complexes 3 [57,58]

Figure 4 Para-halide- and alkyl-substituted bis(arylimino)pyridine-iron pre-catalysts 4 [59]

Figure 5 Bis(arylimino)pyridine-iron complexes, 5, containing $\omega$-alkenyl imine-C substituents [60]

Figure 6 Symmetrical and unsymmetrical bis(arylimino)pyridine-iron complexes 6 [61]

Figure 7 Bis(arylimino)pyridine-iron(II)/(III) complexes 7 [62]

Figure 8 Bis(arylimino)pyridine-substituted iron complexes, 8 , containing boryl groups [63]

Figure 9 Bis(arylimino)pyridine-iron and -cobalt complexes, 9, appended with $\mathrm{N}$-alkenyl groups [64]

Figure 10 4-Pyridyl substituted bis(arylimino)pyridine-iron and -cobalt complexes 10 [65]

Figure 11 Nitro-substituted bis(arylimino)pyridine-iron and -cobalt complexes 11 [66]

Figure 12 Unsymmetrical bis(arylimino)pyridine-iron complexes, 12, with alkyl and halide N-aryl substituents [67].

Figure 13 Bis(arylimino)pyridine-iron complexes bearing bulky ortho-substituted N-aryl groups $\mathbf{1 3}$ [69]

Figure 14 Benzhydryl-substituted bis(arylimino)pyridine-iron and -cobalt complexes 14-31 [70-81]

Figure 15 Iron and cobalt complexes, 32-43, bearing phenanthroline-imines and related ligands [82-91]

Figure 16 Aryl-fused $N, N, N$-iron and -cobalt pre-catalysts 44-50 [92-98]

Figure 17 Related $N, N_{\mathrm{py}}, N$-iron and -cobalt pre-catalysts 51-56 [83,99-105] 
Figure 18 Cyclohexyl-fused bis(arylimino)pyridines (B) as inspired by $\mathbf{D}$ and $\mathbf{A}$ [52-54,106-112]

Figure 19 Singly cycloalkyl-fused (arylimino)pyridyl iron and cobalt pre-catalysts 57-63 [111-117]

Figure 20 Doubly cycloalkyl-fused bis(arylimino)pyridine-iron and -cobalt pre-catalysts 64-67 [119-122]

Figure 21 Representative ${ }^{1} \mathrm{H}$ NMR spectrum of the vinyl-polyethylene obtained using cobalt complex 63 [117]

Figure 22 Representative ${ }^{13} \mathrm{C}$ NMR spectrum of the vinyl-polyethylene obtained using cobalt complex 63 [117]

Figure 23 Iron and cobalt complexes bearing cycloalkyl-fused N,N,O ligands [123]

Figure 24 Isolable bis(arylimino)pyridine-iron alkyl complexes [148,149] 


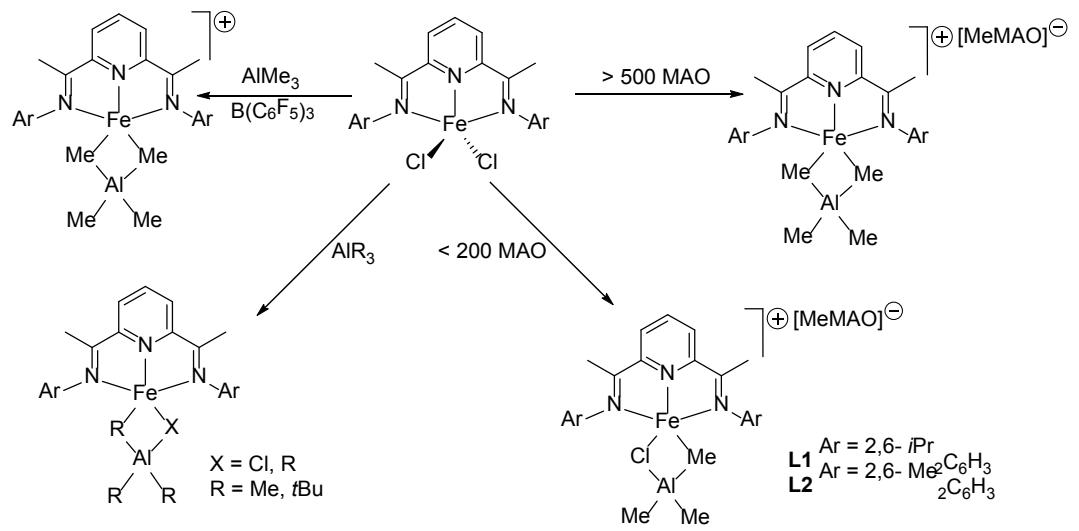

Scheme 1 Reactivity of $\left[(\mathbf{L} 1) \mathrm{FeCl}_{2}\right]$ and $\left[(\mathbf{L} 2) \mathrm{FeCl}_{2}\right]$ towards $\mathrm{MAO}, \mathrm{AlMe}_{3}$ and $\mathrm{AlMe}_{3} / \mathrm{B}\left(\mathrm{C}_{6} \mathrm{~F}_{5}\right)_{3}[44,45$, 129-131]. 


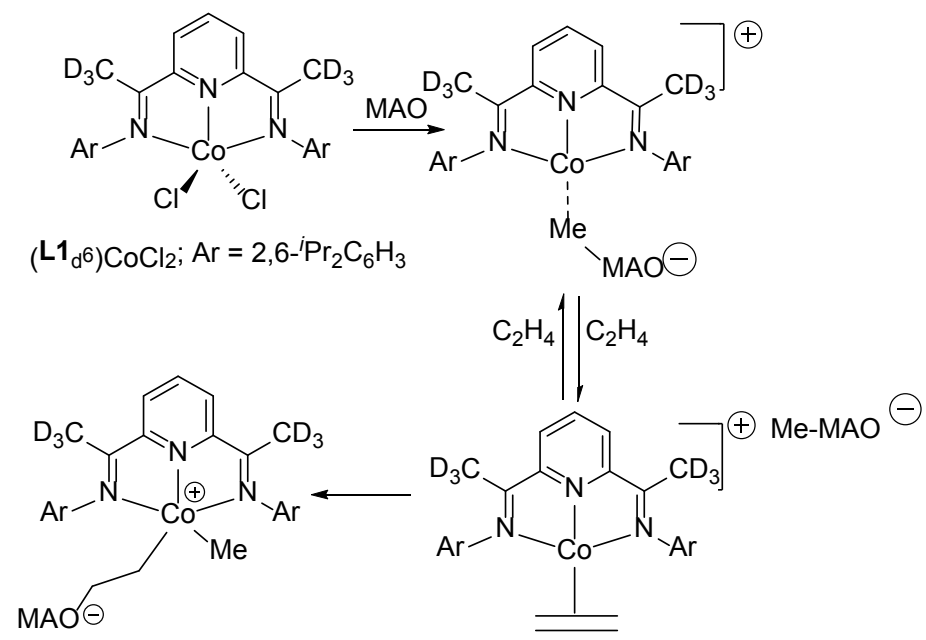

Scheme 2 Proposed mechanism for the activation $\left[\mathbf{L 1}_{d 6} \mathrm{CoCl}_{2}\right]$ with MAO and interaction with ethylene $[44,45,154,155]$ 


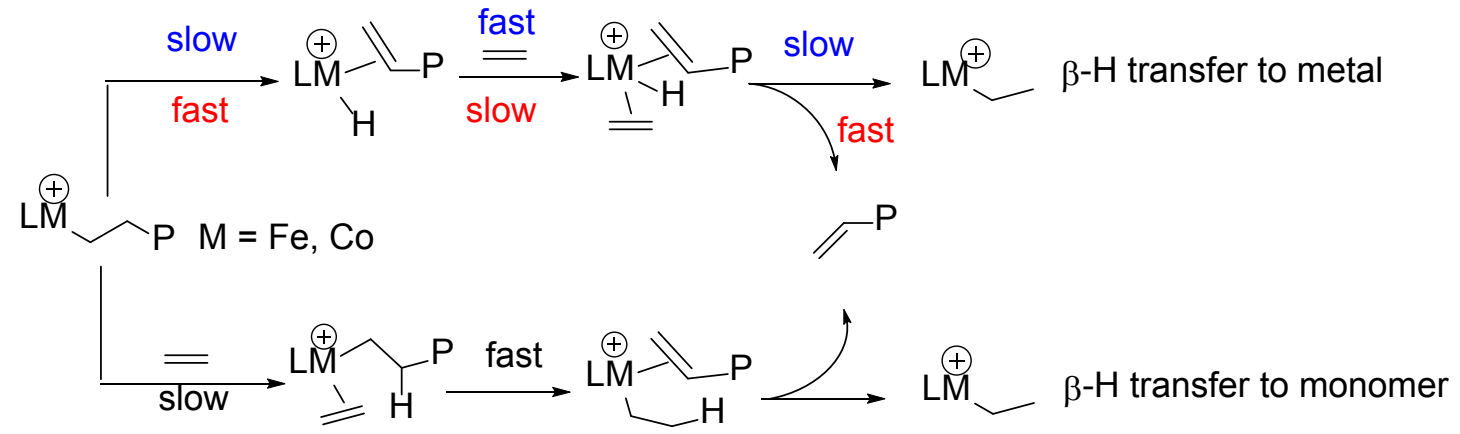

Scheme 3 Two potential mechanisms for the formation of vinyl-polyethylenes $[44,45,56]$ 
Table 1 Catalytic performance of para-halide- and alkyl-substituted bis(arylimino)pyridine-iron pre-catalysts [59]

\begin{tabular}{llllll}
\hline Entry & $\mathrm{X}$ & Activity $^{\mathrm{b}}$ & $M_{\mathrm{n}}{ }^{\mathrm{c}}$ & $M_{\mathrm{w}}{ }^{\mathrm{c}}$ & PDI $^{\mathrm{c}}$ \\
\hline 1 & $\mathrm{Br}$ & 4.11 & 1.94 & 9.29 & 4.80 \\
2 & $\mathrm{I}$ & 14.66 & 2.27 & 10.24 & 4.51 \\
3 & $\mathrm{H}$ & 2.79 & 0.67 & 9.09 & 13.61 \\
4 & $\varnothing$ & 8.98 & 1.62 & 15.80 & 9.70 \\
\hline
\end{tabular}

a Solvent: $250 \mathrm{ml} n$-pentane, activator: $\mathrm{MAO}, \mathrm{Fe}: \mathrm{Al}=1: 2500,10$ bar ethylene;

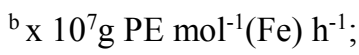

${ }^{\mathrm{c}}$ Determined by GPC and $M_{\mathrm{n}}, M_{\mathrm{w}} \times 10^{4} \mathrm{~g} \mathrm{~mol}^{-1}$. 
Table 2 Variation in the polyethylene properties as a function of the iron and cobalt pre-catalyst structure and temperature. ${ }^{\mathrm{a}}$

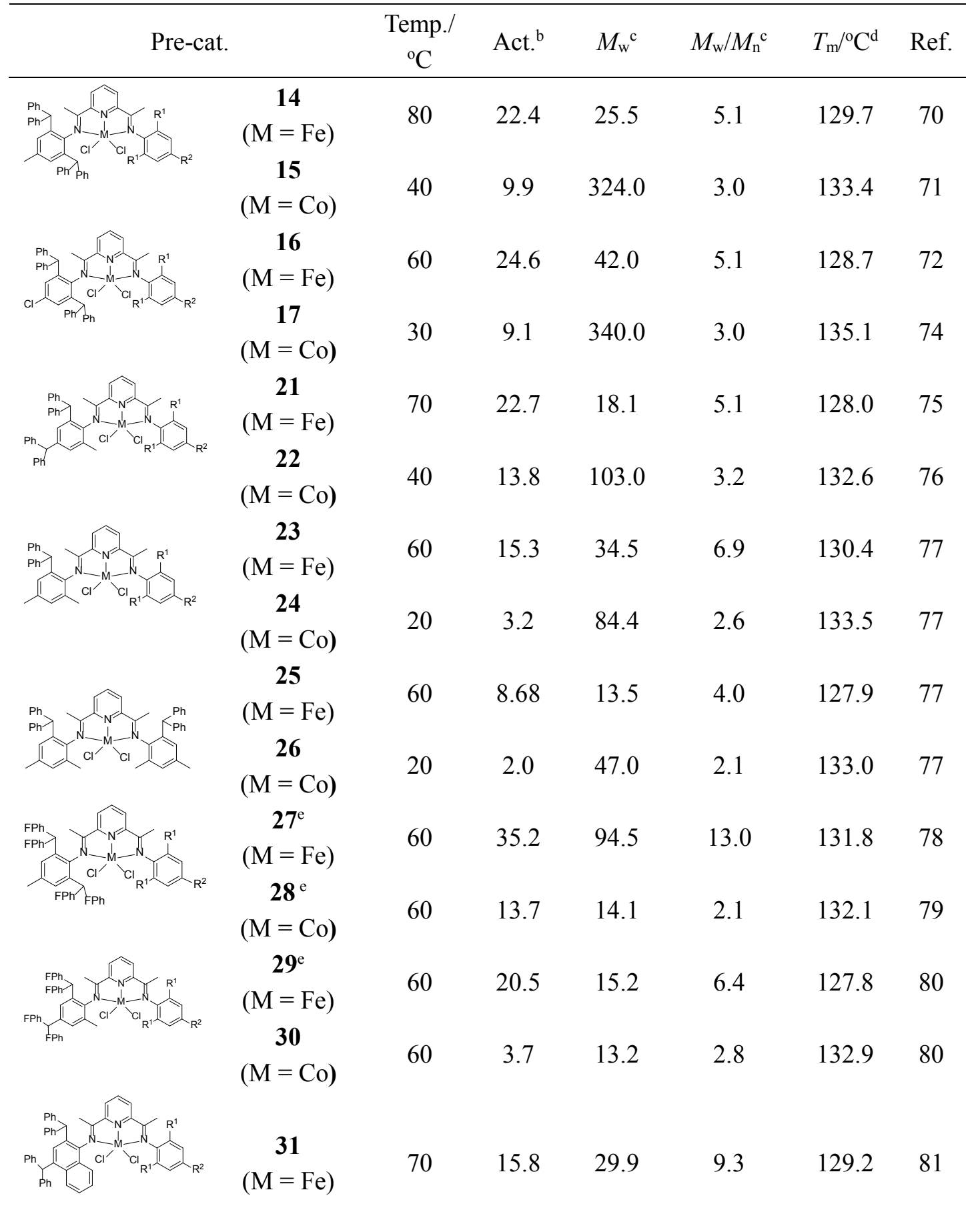

\footnotetext{
${ }^{\text {a }}$ Ethylene pressure $10 \mathrm{~atm} ., 30 \mathrm{~min}$, toluene as solvent and MMAO as activator.

${ }^{\mathrm{b}} \times 10^{6} \mathrm{~g} \mathrm{PE} \mathrm{mol}^{-1}(\mathrm{M}) \mathrm{h}^{-1}, \mathrm{M}=\mathrm{Fe}$ or Co.

${ }^{\mathrm{c}}$ Determined by GPC, $M_{\mathrm{w}}: \mathrm{Kg} \mathrm{mol}^{-1}$.

${ }^{\mathrm{d}}$ Determined by DSC.

e 15 min.
} 
Table 3 Catalytic performance of 2-imino-1,10-phenanthroline-iron complexes ${ }^{a}$

\begin{tabular}{|c|c|c|c|c|c|}
\hline \multirow[b]{2}{*}{ Pre-cat. $(2 \mu \mathrm{mol})$} & \multicolumn{2}{|c|}{ Oligomers } & \multicolumn{3}{|c|}{ Waxes } \\
\hline & $\operatorname{Activity}^{\mathrm{b}}\left(\times 10^{6}\right)$ & $\mathrm{K}$ & $\% \alpha-\mathrm{O}^{c}$ & $A_{\mathrm{w}}{ }^{\mathrm{d}}\left(\times 10^{5}\right)$ & Ref. \\
\hline & 13.3 & 0.58 & $>94$ & 48.6 & 84,85 \\
\hline & 49.1 & 0.62 & $>94$ & 14.6 & 84,85 \\
\hline & 23.0 & 0.52 & $>95$ & 3.2 & 84,85 \\
\hline & 13.9 & 0.70 & $>95$ & 12.1 & 86 \\
\hline & 0.40 & 0.80 & $>99$ & trace & 87 \\
\hline & 1.94 & 0.80 & $>99$ & trace & 87 \\
\hline
\end{tabular}

${ }^{a}$ General conditions: $\mathrm{Al} / \mathrm{Fe}=1000$, temperature $40^{\circ} \mathrm{C}$, time $1 \mathrm{~h}, 100 \mathrm{~mL}$ toluene, $\mathrm{MAO}$ as activator and 10 atm ethylene.

${ }^{\mathrm{b}}$ Activity for oligomers: $\mathrm{g} \mathrm{mol}^{-1}(\mathrm{Fe}) \mathrm{h}^{-1}$.

${ }^{c} \alpha$-Olefin percentage determined by GC and GC-MS.

${ }^{\mathrm{d}}$ Activity for polyethylene (wax): $\mathrm{g} \mathrm{mol}^{-1}(\mathrm{Fe}) \mathrm{h}^{-1}$.

${ }^{\mathrm{e}} \mathrm{Al} / \mathrm{Fe}=1500$, temperature $50{ }^{\circ} \mathrm{C}$. 
2-(2-benzimidazolyl)-6-(1-(arylimino)-ethyl)pyridine-iron pre-catalysts ${ }^{a}$

\begin{tabular}{|c|c|c|c|c|c|}
\hline \multirow[b]{2}{*}{ Pre-cat. $(2 \mu \mathrm{mol})$} & \multicolumn{2}{|c|}{ Oligomers } & \multicolumn{3}{|c|}{ Waxes } \\
\hline & $\operatorname{Activity}^{\mathrm{b}}\left(\times 10^{6}\right)$ & $\mathrm{K}$ & $\% \alpha-\mathrm{O}^{c}$ & $A_{\mathrm{w}}^{\mathrm{d}}\left(\times 10^{5}\right)$ & Ref. \\
\hline & 4.11 & 0.46 & $\geq 99$ & 3.40 & 93 \\
\hline & 1.20 & 0.53 & $>95$ & 3.60 & 94 \\
\hline & 0.86 & 0.60 & $>98$ & 4.48 & 95 \\
\hline & 3.03 & 0.66 & $>99$ & trace & 96 \\
\hline & 2.82 & 0.71 & $>98$ & trace & 96 \\
\hline & 11.00 & 0.43 & $>96$ & 4.91 & 96 \\
\hline
\end{tabular}

\footnotetext{
${ }^{a}$ General conditions: $\mathrm{Al} / \mathrm{Fe}=1000$, temperature $20^{\circ} \mathrm{C}$, time $30 \mathrm{~min}, 100 \mathrm{~mL}$ toluene, MMAO as activator and $10 \mathrm{~atm}$ ethylene.

${ }^{\mathrm{b}}$ Activity for oligomers: $\mathrm{g} \mathrm{mol}^{-1}(\mathrm{Fe}) \mathrm{h}^{-1}$.

${ }^{c} \alpha$-Olefin percentage determined by GC and GC-MS.

${ }^{\mathrm{d}}$ Activity for polyethylene (wax): $\mathrm{g} \mathrm{mol}^{-1}(\mathrm{Fe}) \mathrm{h}^{-1}$.

${ }^{\mathrm{e}} \mathrm{Al} / \mathrm{Fe}=200,30^{\circ} \mathrm{C}$.

${ }^{\mathrm{f}} \mathrm{Al} / \mathrm{Fe}=200,30^{\circ} \mathrm{C}, \mathrm{MAO}$ as activator.

${ }^{\mathrm{g}} \mathrm{Al} / \mathrm{Fe}=750$.
} 
Table 5 Variation in polyethylene properties as a function of the iron pre-catalyst structure, temperature and activity; MAO activation ${ }^{\mathrm{a}}$

\begin{tabular}{|c|c|c|c|c|c|c|}
\hline Pre-cat. & Temp. $/{ }^{\circ} \mathrm{C}$ & Activity $^{\mathrm{b}}$ & $M_{\mathrm{w}}^{\mathrm{c}}$ & $M_{\mathrm{w}} / M_{\mathrm{n}}^{\mathrm{c}}$ & Chain-end types ${ }^{\mathrm{d}}$ & Ref \\
\hline & 50 & 15.60 & 22.7 & 6.3 & both alkyl & 111 \\
\hline & 60 & 9.03 & 31.4 & 9.7 & both alkyl & 114 \\
\hline & 70 & 15.61 & 18.9 & 12.3 & both alkyl & 115 \\
\hline & 30 & 3.71 & 27.7 & 3.6 & both alkyl & 119 \\
\hline & 60 & 12.38 & 18.3 & 18.1 & vinyl/alkyl & 120 \\
\hline
\end{tabular}

${ }^{a}$ Ethylene pressure $10 \mathrm{~atm}$., toluene as solvent and $\mathrm{MAO}$ as activator.

${ }^{\mathrm{b}} \mathrm{x} 10^{6} \mathrm{~g} \mathrm{PE} \mathrm{mol}^{-1}(\mathrm{Fe}) \mathrm{h}^{-1}$.

${ }^{\mathrm{c}}$ Determined by GPC, $M_{\mathrm{w}}: \mathrm{Kg} \mathrm{mol}^{-1}$.

${ }^{\mathrm{d}}$ Determined by ${ }^{1} \mathrm{H}$ and ${ }^{13} \mathrm{C}$ NMR spectroscopy.

${ }^{\mathrm{e}}$ Reaction conditions: ethylene pressure 1.3 bar. 
Table 6 Variation in polyethylene properties as a function of the cobalt pre-catalyst structure, temperature and activity; MAO activation ${ }^{\mathrm{a}}$

\begin{tabular}{|c|c|c|c|c|c|c|}
\hline Pre-cat. & Temp. $/{ }^{\circ} \mathrm{C}$ & Activity $^{b}$ & $M_{\mathrm{w}}^{\mathrm{c}}$ & $M_{\mathrm{w}} / M_{\mathrm{n}}^{\mathrm{c}}$ & Chain-end types ${ }^{\mathrm{d}}$ & Ref. \\
\hline & 60 & 10.90 & 0.90 & 1.5 & both alkyl & 112 \\
\hline & 50 & 0.02 & 325.2 & 5.2 & both alkyl & 113 \\
\hline & 50 & 8.15 & 3.2 & 1.8 & vinyl/alkyl & 116 \\
\hline & 60 & 8.65 & 4.6 & 2.2 & vinyl/alkyl & 117 \\
\hline & 30 & 2.98 & 0.8 & 1.5 & both alkyl & 118 \\
\hline & 40 & 3.69 & 4.6 & 2.1 & vinyl/alkyl & 121 \\
\hline & 30 & 2.89 & 423.0 & 2.7 & alkyl-end & 122 \\
\hline
\end{tabular}

${ }^{\mathrm{a}}$ Ethylene pressure $10 \mathrm{~atm}$., toluene as solvent and MAO as activator.

${ }^{\mathrm{b}} \mathrm{x} 10^{6} \mathrm{~g} \mathrm{PE} \mathrm{mol}^{-1}(\mathrm{Co}) \mathrm{h}^{-1}$.

${ }^{\mathrm{c}}$ Determined by GPC, $M_{\mathrm{w}}: \mathrm{Kg} \mathrm{mol}^{-1}$.

${ }^{\mathrm{d}}$ Determined by ${ }^{1} \mathrm{H}$ and ${ }^{13} \mathrm{C}$ NMR spectroscopy.

${ }^{\mathrm{e}}$ Reaction conditions: ethylene pressure 1.3 bar. 


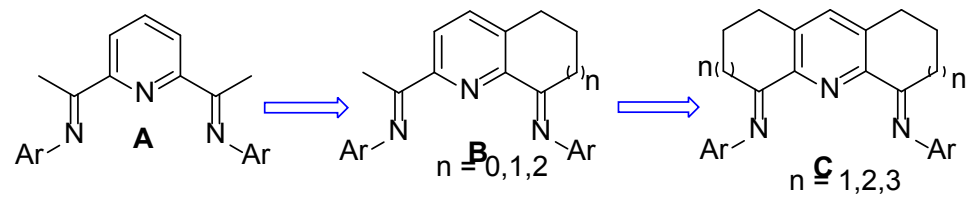

Figure 1 Evolution of the bis(arylimino)pyridine ligand frame (A) through incorporation of carbocyclic-fused units to give $\mathbf{B}$ and $\mathbf{C}[43,46,51-54]$
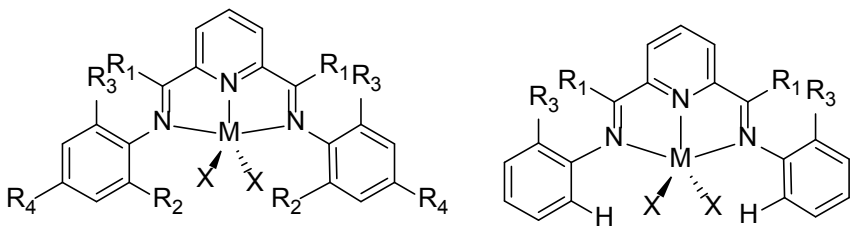

1

$\mathrm{M}=\mathrm{Fe}, \mathrm{Co} ; \mathrm{X}=\mathrm{Cl}, \mathrm{Br} \quad 2$

Figure 2 First generation bis(arylimino)pyridine-iron(II) and -cobalt(II) pre-catalysts 1 and 2 [52-56]

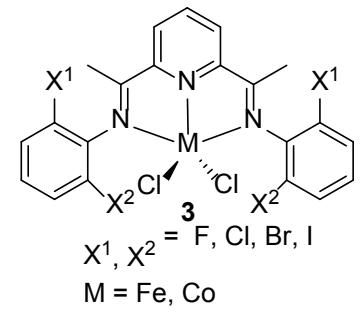

Figure 3 Halide-substituted bis(arylimino)pyridine-iron and -cobalt complexes 3 [57,58]

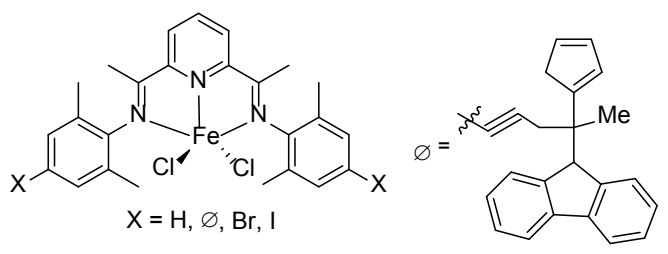

Figure 4 Para-halide- and alkyl-substituted bis(arylimino)pyridine-iron pre-catalysts 4 [59]

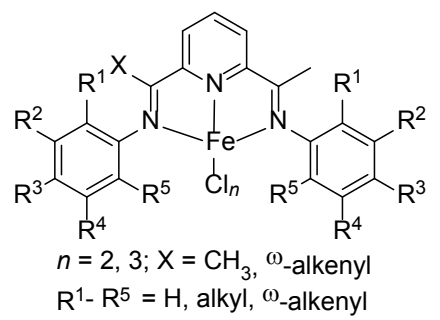

Figure 5 Bis(arylimino)pyridine-iron complexes, 5, containing $\omega$-alkenyl imine-C substituents [60] 


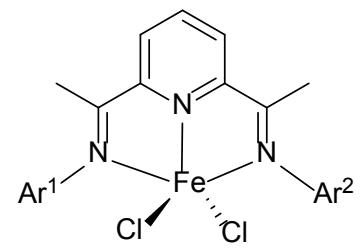

6a $\mathrm{Ar}^{1}, \mathrm{Ar}^{2}=2,6$-diisopropylphenyl

6b $\mathrm{Ar}_{1}, \mathrm{Ar}^{2}=1$-anthracenyl

6c $\mathrm{Ar}_{1}, \mathrm{Ar}^{2}=2$-isopropylphenyl

6d $\mathrm{Ar}_{1}, \mathrm{Ar}^{2}=2$-biphenyl

6e $\mathrm{Ar}_{1}=2,6$-diisopropylphenyl, $\mathrm{Ar}^{2}=1$-anthracenyl

$6 \mathrm{Ar}_{1}=2,6$-diisopropylphenyl, $\mathrm{Ar}^{2}=2$-isopropylphenyl

Figure 6 Symmetrical and unsymmetrical bis(arylimino)pyridine-iron complexes 6 [61]

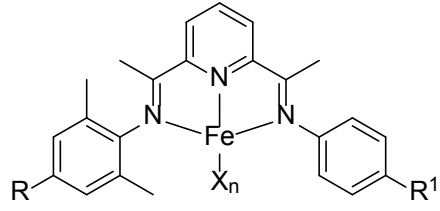

$\mathrm{R}=\mathrm{H}, \mathrm{Me}, \mathrm{Br} ; \mathrm{X}=\mathrm{Cl}, \mathrm{Br} ; \mathrm{n}=2,3$

$$
\begin{aligned}
& 7 \mathrm{a} \\
& 7 \mathrm{~b}
\end{aligned} \mathrm{R}_{1}^{1}=\mathrm{H}
$$

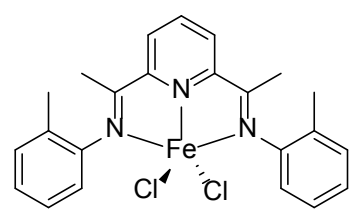

$7 c$

Figure 7 Bis(arylimino)pyridine-iron(II)/(III) complexes 7 [62]

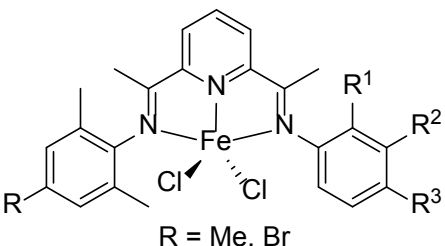

8

$$
\begin{aligned}
& { }_{8} \mathrm{a}^{\mathrm{R}_{1}}=\varnothing, \mathrm{R}^{2}=\mathrm{R}^{3}=\mathrm{H} \\
& 8 b R^{2}=\varnothing, R^{1}=R^{3}=H \\
& { }_{8} c^{R_{3}}=\varnothing, R^{1}=R^{2}=H
\end{aligned}
$$

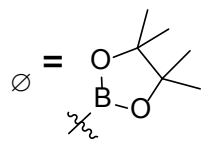

Figure 8 Bis(arylimino)pyridine-substituted iron complexes, 8, containing boryl groups [63]

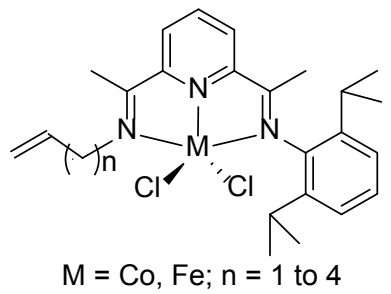

9

Figure 9 Bis(arylimino)pyridine-iron and -cobalt complexes, 9, appended with N-alkenyl groups [64]

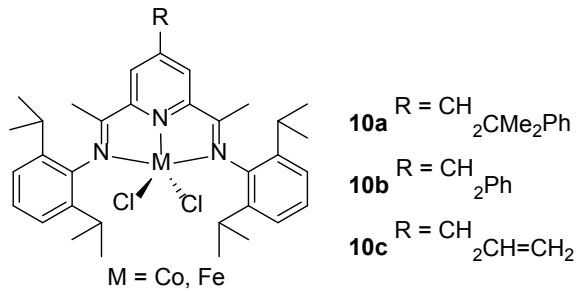

Figure 10 4-Pyridyl substituted bis(arylimino)pyridine-iron and -cobalt complexes 10 [65] 


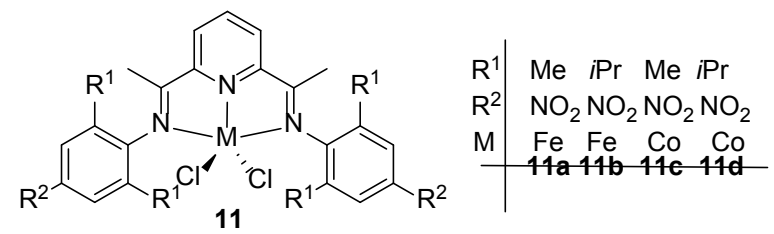

Figure 11 Nitro-substituted bis(arylimino)pyridine-iron and -cobalt complexes 11 [66]

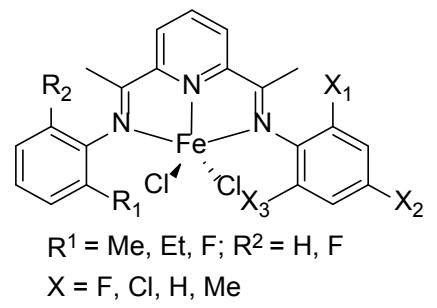

12

Figure 12 Unsymmetrical bis(arylimino)pyridine-iron complexes, 12, with alkyl and halide $\mathrm{N}$-aryl substituents [67]

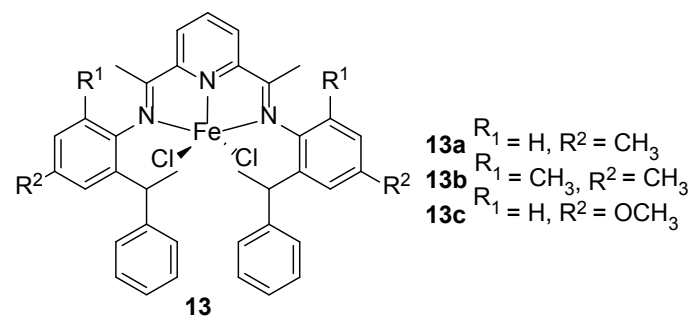

Figure 13 Bis(arylimino)pyridine-iron complexes bearing bulky ortho-substituted N-aryl groups 13
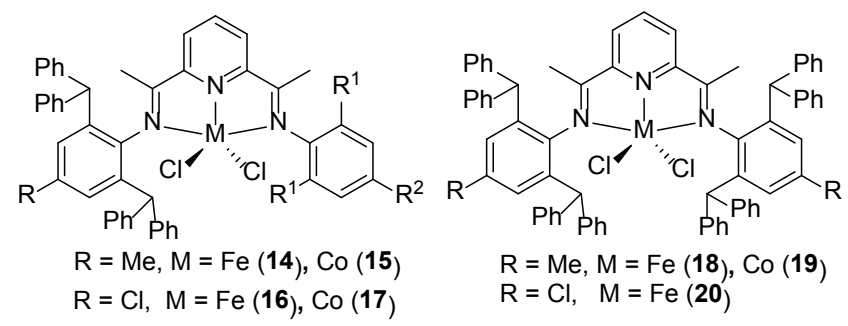

$$
\begin{aligned}
& \mathrm{R}=\mathrm{Me}, \mathrm{M}=\mathrm{Fe}(\mathbf{1 8}), \mathrm{Co}(\mathbf{1 9}) \\
& \mathrm{R}=\mathrm{Cl}, \mathrm{M}=\mathrm{Fe}(\mathbf{2 0})
\end{aligned}
$$

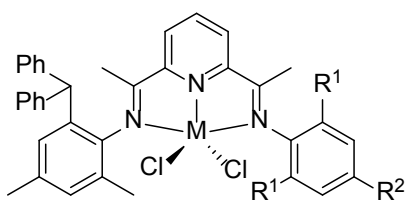

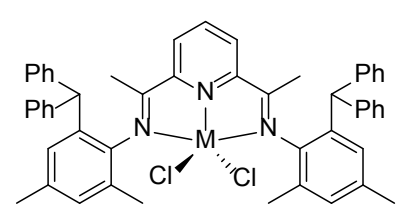

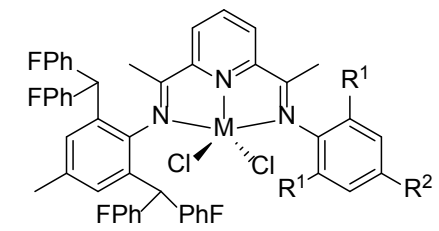

$$
M=F e(\mathbf{2 3}) \text {, Co (24) }
$$

$$
M=F e(\mathbf{2 5}), C o(\mathbf{2 6})
$$

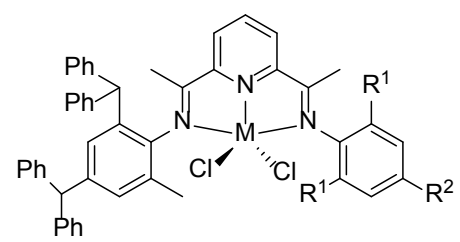

$$
M=F e(\mathbf{2 1}), C o(\mathbf{2 2})
$$

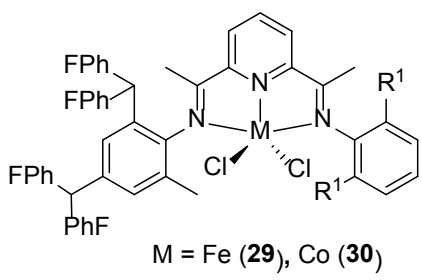

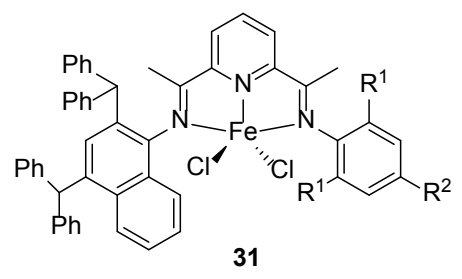


Figure 14 Benzhydryl-substituted bis(arylimino)pyridine-iron and -cobalt complexes 14-31 [70-81]

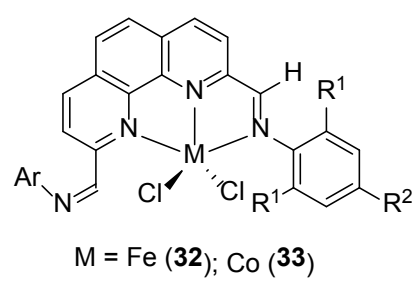

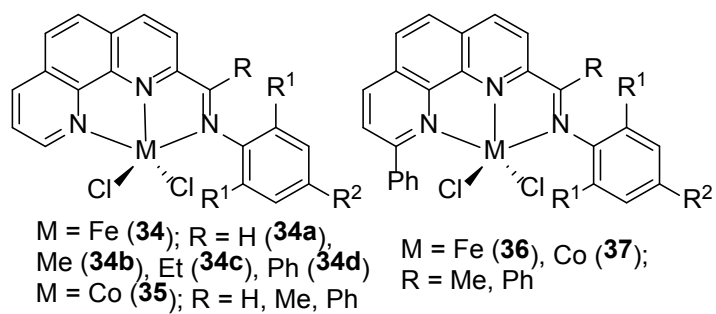

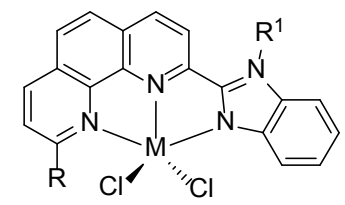

$M=F e(38)$, Co (39); R = H, Me; $\mathrm{R}^{1}=\mathrm{H}, \mathrm{Me}, \mathrm{Et}, i-\mathrm{Pr}, \mathrm{Bn}$

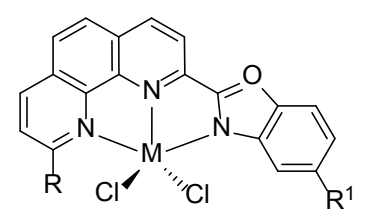

$\mathrm{M}=\mathrm{Fe}(\mathbf{4 0})$, Co $(\mathbf{4 1})$; $\mathrm{R}=\mathrm{H}, \mathrm{Ph} ; \mathrm{R}^{1}=\mathrm{H}, \mathrm{Me}, t-\mathrm{Bu}$

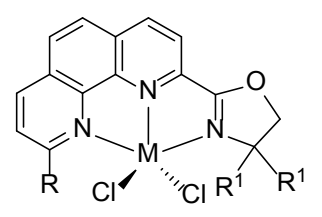

$\mathrm{M}=\mathrm{Fe}(\mathbf{4 2})$, Co $(\mathbf{4 3})$; $\mathrm{R}=\mathrm{H}, \mathrm{Ph} ; \mathrm{R}^{1}=\mathrm{H}, \mathrm{Me}$

Figure 15 Iron and cobalt complexes, 32-43, bearing phenanthroline-imines and related ligands [82-91]

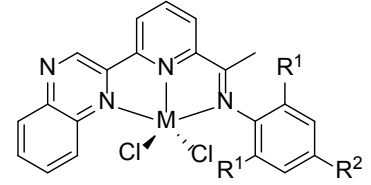

$\mathrm{M}=\mathrm{Fe}(\mathbf{4 4})$, Co $(\mathbf{4 5})$

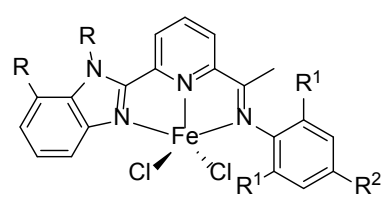

$\mathrm{R}=\mathrm{Me}(\mathbf{4 8 a}), \mathrm{Cl}(\mathbf{4 8 b})$

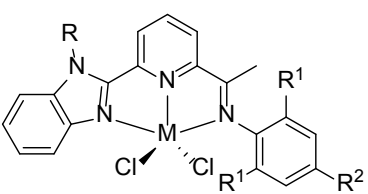

$M_{\bar{R}}=F_{\bar{H}}\left(4 G_{i \notin}, k p_{r}(47)\right.$

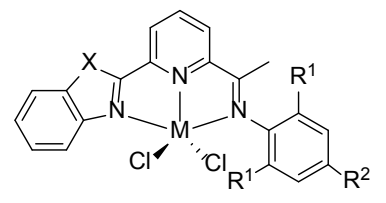

$\mathrm{X}=\mathrm{O} ; \mathrm{M}=\mathrm{Co}(\mathbf{4 9}$

$\mathrm{X}=\mathrm{S} ; \mathrm{M}=\mathrm{Fe}(\mathbf{5 0}), \mathrm{Co}(\mathbf{5 1})$

Figure 16 Aryl-fused $N, N, N$-iron and -cobalt pre-catalysts 44-50 [92-98]

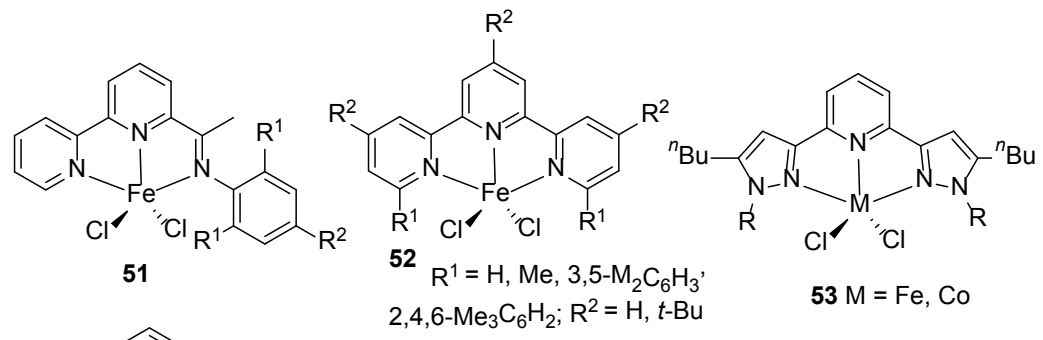

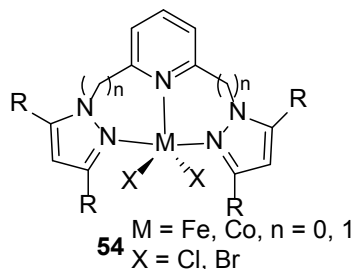

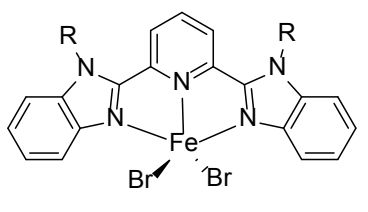

55

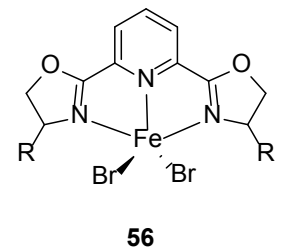

56

Figure 17 Related $N, N_{\text {py }}, N$-iron and -cobalt pre-catalysts 51-56 [83,99-105] 


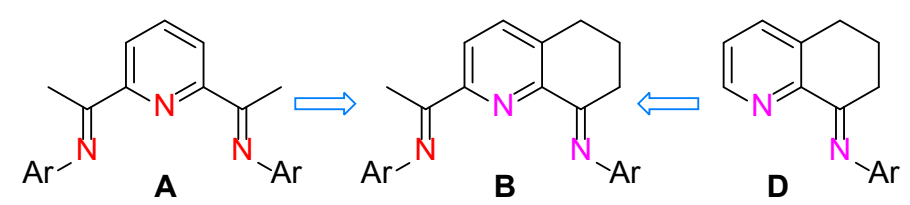

Figure 18 Cyclohexyl-fused bis(arylimino)pyridines (B) as inspired by $\mathbf{D}$ and $\mathbf{A}$ [52-54,106-112]
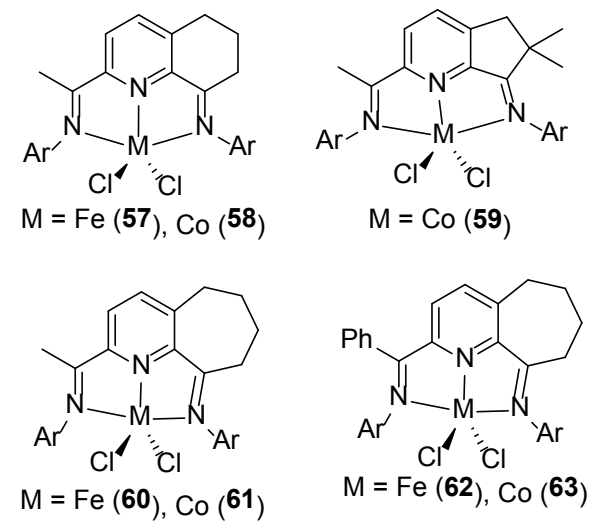

Figure 19 Singly cycloalkyl-fused (arylimino)pyridyl iron and cobalt pre-catalysts 57-63 [111-117]
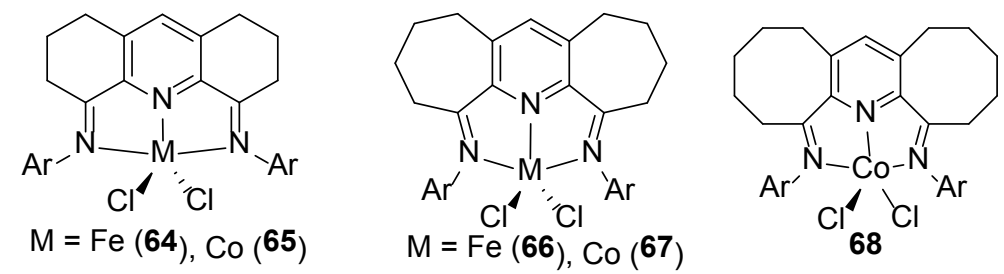

Figure 20 Doubly cycloalkyl-fused bis(arylimino)iminopyridine-iron and -cobalt pre-catalysts 64-68 [119-122]
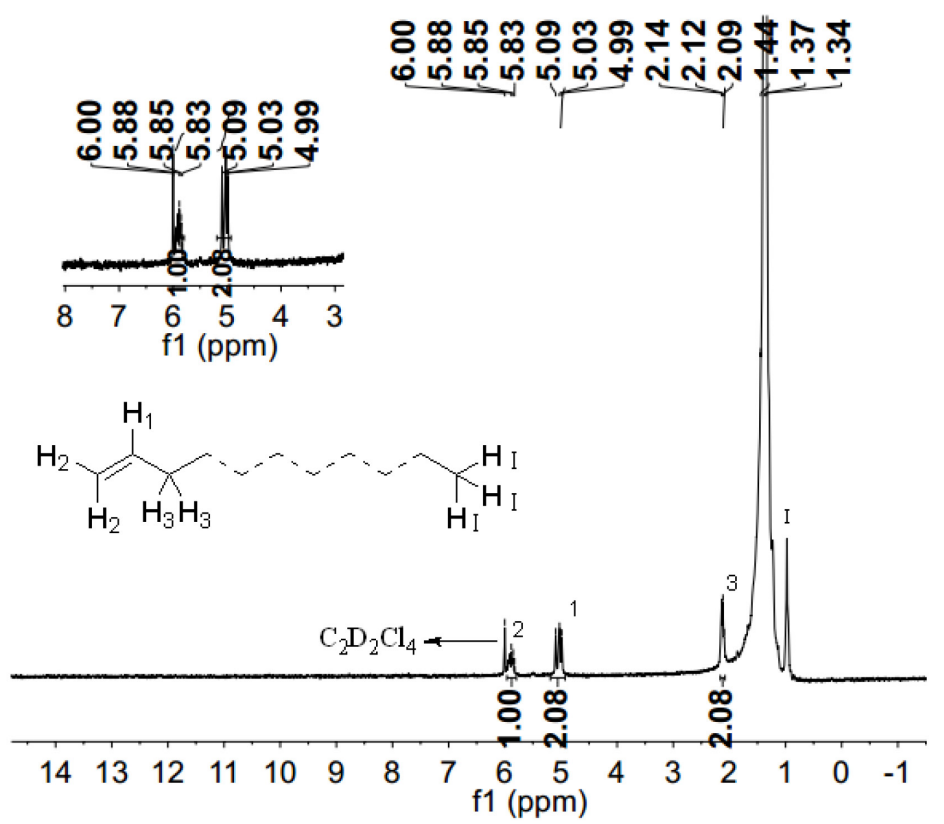

Figure 21 Representative ${ }^{1} \mathrm{H}$ NMR spectrum of the vinyl-polyethylene obtained using cobalt complex 63 [117] 


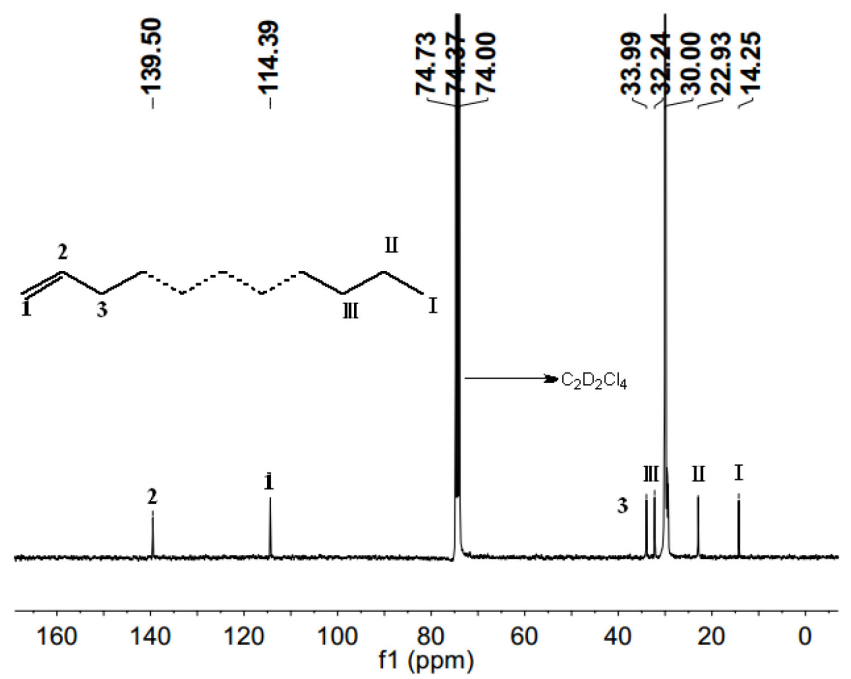

Figure 22 Representative ${ }^{13} \mathrm{C}$ NMR spectrum of the vinyl-polyethylene obtained using cobalt complex 63 [117]

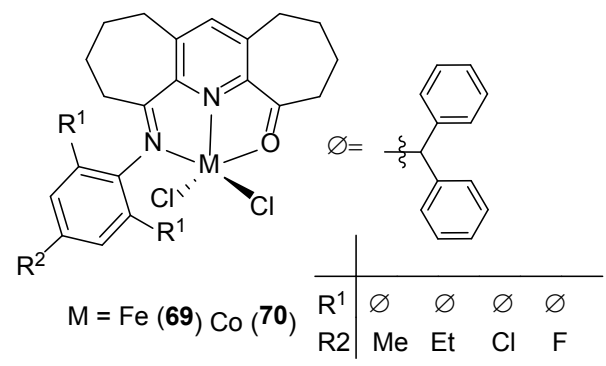

Figure 23 Iron and cobalt complexes bearing cycloalkyl-fused $N, N, O$ ligands [123]

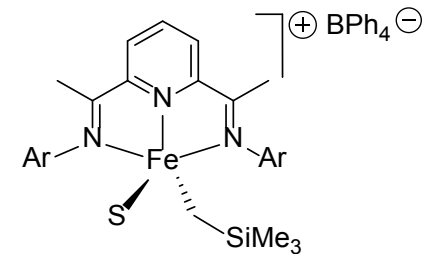

$\mathrm{S}=\mathrm{Et}_{2} \mathrm{O}, \mathrm{THF} ; \mathrm{Ar}=2,6-{ }^{i} \mathrm{Pr}_{2} \mathrm{C}_{6} \mathrm{H}_{3}$

$\left[(\mathrm{L1}) \mathrm{Fe}\left(\mathrm{CH}_{2} \mathrm{SiMe}_{3}\right)(\mathrm{S})\right]^{+}[\mathrm{BPh} 4]^{-}$

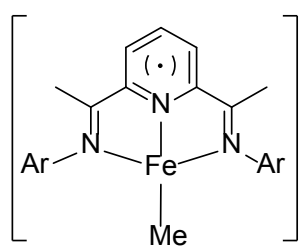

$\left[\left(\mathbf{L}^{1}\right) \mathrm{FeCH}_{3}\right]$

Figure 24 Isolable bis(arylimino)pyridine-iron alkyl complexes [148,149] 